University of Chicago Law School

Chicago Unbound

Journal Articles

Faculty Scholarship

1996

\title{
The Regulation of Groups: The Influence of Legal and Nonlegal Sanctions on Collective Action
}

Eric A. Posner

Follow this and additional works at: https://chicagounbound.uchicago.edu/journal_articles

Part of the Law Commons

\section{Recommended Citation}

Eric Posner, "The Regulation of Groups: The Influence of Legal and Nonlegal Sanctions on Collective Action," 63 University of Chicago Law Review 133 (1996).

This Article is brought to you for free and open access by the Faculty Scholarship at Chicago Unbound. It has been accepted for inclusion in Journal Articles by an authorized administrator of Chicago Unbound. For more information, please contact unbound@law.uchicago.edu. 


\title{
The Regulation of Groups: The Influence of Legal and Nonlegal Sanctions on Collective Action
}

\author{
Eric A. Posner $\dagger$
}

Most people do not take their disputes to lawyers and judges. Norms, rather than laws, provide the rules of conduct; friends, relatives, and coworkers, rather than juries, make findings of fact; shame and ostracism, rather than imprisonment or legal damages, punish the wrongdoer. Court is held not in a courthouse, but in homes, work places, and neighborhoods, among networks of kin, friends, and associates. In a sufficiently closeknit group, where norms are well defined and nonlegal sanctions are effective, the law has little impact on behavior.

These claims are not original. The legal realists advanced them in the 1920s and 1930 s as a critique of the formalism that then dominated legal scholarship.' Members of the law and society movement reiterated them in the 1960 s and 1970 s. $^{2}$ Such claims provided the occasion, and even the philosophical basis, for much of the empirical research conducted by legal academics over the years. ${ }^{3}$ And it seems fair to say that most legal academics endorse them today. ${ }^{4}$ Yet these claims about the predominance of nonlegal sanctions and the relative unimportance of the

$\dagger$ Assistant Professor of Law, University of Pennsylvania. I thank Scott Altman, Jonathan Baron, Lisa Bernstein, Steve Croley, Emlyn Eisenach, Robert Ellickson, Mike Fitts, David Friedman, Ron Garet, Jeff Gordon, Sarah Barringer Gordon, Alon Harel, Geoffrey Hazard, Avery Katz, Leo Katz, Howard Lesnick, Saul Levmore, John Lott, Ed McCaffery, Ed Rock, Reed Shuldiner, Kate Silbaugh, Susan Sturm, Manuel Utset, and participants at talks at the University of Pennsylvania, Georgetown University, The University of Chicago, and the University of Southern California, and at the 1995 annual meeting of the American Law and Economics Association. I especially thank Richard Craswell and Jason Johnston for their generous comments.

1 See, for example, Karl N. Llewellyn, What Price Contract?-An Essay in Perspective, 40 Yale L J 704, 712-14 (1931). See generally William Twining, Karl Llewellyn and the Realist Movement 35-36 (Oklahoma 1973).

2 See, for example, Stewart Macaulay, Non-Contractual Relations in Business: A Preliminary Study, 28 Am Soc Rev 55, 62-67 (1963). For a recent discussion of the movement, see Symposium, Law, Private Governance and Continuing Relationships, 1985 Wis L Rev 461.

${ }^{3}$ For examples, see notes 85-93 and accompanying text.

4 See, for example, Symposium, The Informal Economy, 103 Yale L J 2119 (1994). 
law have a curiously muted presence in legal discourse. They exist more as unstated qualifications to legal arguments than as independent propositions-that is to say, most commentators would agree that their claims apply only to the limited cases where the law matters, but would also insist that this proposition is obvious and not worth exploring. In short, legal academics generally have not incorporated the realist insight into their scholarship in an interesting way. ${ }^{5}$ Why is this?

The most likely reason is that scholars have implicitly adopted what I will call an "insulation theory" of nonlegal sanctions. This theory can be described in the following way. When nonlegal sanctions govern certain kinds of behavior, they reduce the influence of the law, but they do not eliminate it. It is as though the nonlegal sanctions surround the affected individuals with a layer of insulation: in order for the law to influence those individuals, legal sanctions must be strong enough to penetrate the inhibitive layer of nonlegal sanctions. But although nonlegal sanctions diminish the effect of the law, they do so in a uniform and predictable way, just as insulation keeps out cold or noise in a uniform way. Thus, nonlegal sanctions do not present a problem for legal analysis. After one concludes that law $\mathrm{X}$ is the optimal means for producing behavior $\mathrm{Y}$, one might observe that the legal sanction associated with $\mathrm{X}$ may need to be strengthened in order to overcome the interference of nonlegal sanctions that independently discourage $Y$. But this is hardly an interesting point, and scholars can be forgiven for neglecting to make it in every one of their arguments.

The problem with the insulation theory is that a law $\mathrm{X}$ not only influences some behavior $\mathrm{Y}$ directly by applying a sanction to it; it also modifies the dynamics of groups with an interest in that behavior. As such groups are the sources of nonlegal sanctions, the law influences the behavior $\mathrm{Y}$ both through the direct application of its sanctions and through its effect on the groups whose nonlegal sanctions influence that behavior. When one takes account of both the direct and the group effects, the analy-

${ }^{5}$ However, valuable efforts at such incorporation include Robert C. Ellickson, Order Without Law: How Neighbors Settle Disputes 141-47 (Harvard 1991), and David Charny, Nonlegal Sanctions in Commercial Relationships, 104 Harv L Rev 373, 391-446 (1990). See also Lisa Bernstein, Grant Proposal, The Newest Law Merchant: Private Commercial Law in the United States (1995) (on file with U Chi L Rev). The law and society literature is highly empirical and offers few generalizations about the interaction between legal and nonlegal sanctions. See Lawrence M. Friedman, The Law and Society Movement, 38 Stan L Rev 763, 766-73 (1986). 
sis of law X's effect on behavior $\mathrm{Y}$ becomes considerably more complex. The insulation metaphor fails. Nonlegal sanctions interact with the law not in a uniform and predictable way, but in a complicated and surprising way.

To shed light on this interaction, this Article addresses two closely related descriptive questions. ${ }^{6}$ First, under what conditions will nonlegal sanctions subvert legal rules and cause them to produce no effect or even the opposite of the intended effect? Second, how can the state exploit the existence of nonlegal sanctions in order to attain its goals most effectively? The second question gives rise to an additional, seemingly paradoxical, query: how can the state use the law to promote cooperation that is spontaneous, that is, not enforced by the law?

To answer these questions, the Article uses a simplified model of group cooperation. Part I describes this model. Its salient features are the concepts of "solidarity," "group," and "category." "Solidarity" denotes the ability of people to cooperate in the absence of legal sanctions. By "group," I mean a collection of people who choose to cooperate, for example, members of a union local. Finally, a "category" is a collection of people who happen to share some characteristic, for example, employees, but who do not necessarily cooperate with each other. The model employs standard economic concepts to describe the conditions under which cooperation is likely to occur.

Part II describes how modifications of legal rules affect cooperative behavior. This Part introduces a tripartite typology of legal rules, which facilitates generalization about how the law influences groups' collective action. The model described in Part I is used to show how each kind of legal rule undermines or promotes the cooperative behavior of groups, and how, in affecting such behavior, it influences aggregate social wealth and the distribution of resources.

Part III applies the ideas developed in Parts I and II to case studies, including informal business or trade groups (such as the "kye"), unions, religious associations, and families. It should be

- The Article does not make normative claims. Sometimes, for convenience, I state that the state "should" do something. But the context should make clear that such a claim is based on an assumption about what the state's goals might be in a particular context, not on a conviction about whether those goals are proper.

${ }^{7}$ A kye is a rotating credit group formed by Korean immigrants and their descendants to permit its members to save and lend money without resorting to banks. A rotating credit group consists of approximately ten to thirty people who agree to make periodic monetary contributions to a pot. At the end of each period, one of the members HeinOnline -- 63 U. Chi. L. Rev. 1351996 
noted, however, that the theory also applies to other groups, such as Indian tribes, political organizations, charitable institutions, schools, academic departments, law reform committees, professional associations, social clubs, cliques, and neighborhood associations. Part III shows the radical implications for legal analysis that result from attention to the influence of nonlegal sanctions; it is thus, in the tradition of legal realism, a rebuke to those who continue to ignore them.

The analysis yields three unintuitive, albeit preliminary, claims. First, when groups are sufficiently cohesive, or solidary, and pursue goals that are consistent with the state's, transferring resources to them is a more efficient method for obtaining those goals than conventional regulation of individual action. Second, benevolent forms of general regulation that transfer wealth, power, or privileges to deserving segments of the population can have perverse results. In some situations, such regulations will undermine the efforts of groups that would independently achieve the regulations' goals more effectively than the regulations themselves. Indeed, under certain conditions, a policy of simultaneously enacting such regulations and subsidizing certain cooperative groups (namely, those that draw their members from the segment of the population benefitted by the regulations) produces an undesirable or indeterminate result, because the two actions have offsetting effects on incentives to cooperate. Finally, legal rules designed to regulate intragroup relations reduce the group's ability to regulate its members. In fact, with the exception of rules that deter extreme bad faith conduct, even rules that merely duplicate the group's own norms will generally undermine self-regulation.

The Article shows that the following propositions may be true: enforcement of voluntary contracts does not maximize their value to the parties; employment law and labor law undermine each other; aggressive enforcement of criminal law weakens lawabiding religious groups; antidiscrimination laws injure ethnic groups; wealth transfers from the general population to unions and trade groups increase social wealth; and welfare laws reduce the aggregate wealth of the poor. 


\section{A THEORY OF GROUP SOLIDARITY}

People can best obtain the ends they desire in some cases by engaging in cooperative behavior and in others by acting independently. Suppose, for example, that an employee seeks a higher wage. The cooperative method is to join a union; the independent method is to threaten to quit and take another job. Successful cooperation is generally more effective than independent action because cooperation allows people to pool resources and divide tasks. But cooperation also involves costs, such as the cost of coordinating multiple actors, that the independent actor does not incur. Thus, an actor will choose cooperation over independent action only if the increased value of the benefits-that is, the "surplus" resulting from cooperation-exceeds the cost of cooperation. ${ }^{8}$

Having joined a cooperative venture, the actor's calculus changes. Depending on the incentives he faces, the actor will (1) cooperate, (2) free ride (in other words, defect), or (3) revert to independent action. In the labor union example, the actor will either pay dues and participate in strikes (cooperate), pretend to pay dues or promise to participate in strikes but then fail to do so (defect), or quit the union and confront the employer on his own (resume independent action). The payoff from cooperation equals the actor's share of the cooperative surplus less the actor's cooperation cost. The payoff from defection equals the actor's share of the cooperative surplus less the expected cost associated with detection and sanction, which may involve anything from simply being denied one's share of the collective good (that is, ostracism), to something worse, like humiliation or corporal pun-

* Consider the following matrix, which represents the choices faced by two players (for example, employees) as to whether to cooperate (for example, unionize) or act independently:

\begin{tabular}{l|c|c|}
\multicolumn{1}{c}{} & Cooperate & Independent \\
\cline { 2 - 3 } Cooperate & 10,10 & 3,6 \\
\hline Independent & 6,3 & 4,4 \\
\hline
\end{tabular}

It is a necessary, but not sufficient, condition for cooperation (that is, for the existence of a unique Nash equilibrium at which cooperation occurs) that the payoffs when both parties cooperate exceed the payoffs when both parties act independently. In this case, two actors equally divide the joint surplus of 12 (total payoff if both players cooperate - total payoff if both players act independently $=20-8$ ). If the payoffs from cooperation were, say, $(2,2)$, then there would be no joint surplus and no cooperation would occur. 
ishment. The payoff from independent action includes neither a share of the cooperative surplus nor any cost of cooperation. ${ }^{9}$

Even when cooperation produces a joint surplus over independent action, the actors often will not cooperate. As the prisoner's dilemma shows, the problem is that each actor finds it rational to cheat. Suppose, for example, that an employee believes that other employees will cooperate to form a union. Then, to the extent the employee can shirk without being detected and punished, he will do so. As a result, he will continue to receive a share of the surplus while simultaneously avoiding the costs of cooperation. Moreover, if the employee believes that other employees will, using the same logic, behave similarly, resulting in no surplus being produced, then the employee has no incentive to incur the costs of cooperation. So, whatever the other employees do, he will not cooperate. The others, thinking similarly, will also not cooperate. ${ }^{10}$

This dilemma occurs frequently because the collective good, by its nature, can be enjoyed by people who do not participate in its creation. No one produces the good, therefore, because no one has much incentive to participate in its creation. In our example, the employees will act independently rather than embark on a

9 Consider the following matrix:

\begin{tabular}{l|c|c|c|}
\multicolumn{1}{c}{} & \multicolumn{1}{c}{ Cooperate } & Defect & \multicolumn{1}{c|}{ Independent } \\
\cline { 2 - 4 } Cooperate & 8,8 & 0,9 & \\
\cline { 2 - 4 } Defect & 9,0 & 2,2 & \\
\cline { 2 - 4 } Independent & & & 6,6 \\
\cline { 2 - 4 } & & &
\end{tabular}

The numbers in this matrix represent a case where the parties do better by cooperating than by acting alone (joint surplus = joint payoff when both parties cooperate - joint payoff when both parties act alone $=16-12=4$ ). However, if one player cooperates, the other can profit at the first player's expense by cheating. Mutual defection is assumed to be less valuable than mutually independent action. This is because mutual defection involves a costly preliminary effort to go through the forms of cooperation (in an effort to deceive the other party). The blank payoffs reflect the fact that an independent actor does not pretend to cooperate, so no one would try to cooperate with him or could defect against him.

Loosely speaking, this is a two-stage game: In the first stage, if either player acts independently, the game ends with the independent-independent payoff. In the second stage, the players, having announced a commitment to cooperation, decide whether or not to cheat. (Although the matrix represents a two-player game, the conclusions hold also for the n-person games that are the subject of this argument.)

${ }^{10}$ For discussions of the prisoner's dilemma, see Douglas G. Baird, Robert $H$. Gertner, and Randal C. Picker, Game Theory and the Law 33-35 (Harvard 1994); Eric Rasmusen, Games and Information 27-37 (Blackwell 1989). 
hopeless effort to unionize. Employees will not try to deceive each other because it is obvious to everyone that this is what everyone will do. ${ }^{11}$

Obviously, however, groups do solve the problem of cooperation. Although a theory that explains the solution has so far eluded social scientists, ${ }^{12}$ it is clear that the solution must involve the creation of mechanisms to detect and punish defectors. ${ }^{13}$ In a union, for example, members monitor each other to ensure participation in cooperative activity and union leaders keep records of rule infractions. Defectors face criticism by leaders and members, expulsion from the union, and even ostracism from the community. Thus, in a well functioning group, the prisoner's dilemma either does not exist or exists only at the margin: members (or most members) cooperate because the payoff from cooperation exceeds the payoff from defection (as dis-

1 The two-by-two grid forming the northwest corner of the matrix in note 9 represents a prisoner's dilemma. Each player reasons: if the other cooperates, defection is superior $(9>8)$; if the other defects, defection remains superior $(2>0)$. In such a game, the outcome (defined by the dominant strategy equilibrium) is defect-defect. However, since the game I am suggesting is a two-stage game, the players can avoid the defectdefect outcome by choosing independent action in the first stage. They will do so since the independent-independent payoff of 6 exceeds the defect-defect payoff of 2 . Nevertheless, the independent-independent outcome is inferior to the cooperate-cooperate outcome.

12 The literature on the issue of how rational actors cooperate is vast, and the question is unresolved. Economic theories of cooperation predict less cooperation than actually exists. Theories that relax some of the assumptions of the rational actor model have not met with widespread acceptance. Nevertheless, this literature is useful. Even if it does not accurately predict the extent of cooperation, it does help identify the conditions under which cooperation is more likely than not to occur. Helpful contributions and surveys include Dennis C. Mueller, Public choice II: A revised edition of Public Choice 9-36 (Cambridge 1989); Robert H. Frank, Passions Within Reason: The Strategic Role of the Emotions 134-45 (Norton 1988); Michael Hechter, Principles of Group Solidarity 40-58 (California 1987); Robert Axelrod, The Evolution of Cooperation 124-41 (Basic Books 1984); Edna Bonacich and John Modell, The Economic Basis of Ethnic Solidarity: Small Business in the Japanese American Community 24-36 (California 1980); Jon Elster, The Cement of Society: A Study of Social Order 34-49 (Cambridge 1989); Mancur Olson, Jr., The Logic of Collective Action: Public Goods and the Theory of Groups 22-36 (Harvard 1965); Russell Hardin, Collective Action 38-154 (Johns Hopkins 1982); Jon Elster, Solomonic Judgments: Studies in the Limitations of Rationality (Cambridge 1989); James S. Coleman, Foundations of Social Theory 197-240 (Belknap 1990); Elinor Ostram, Roy Gardner, and James Walker, Rules, Games, and Common-Pool Resources 319-29 (Michigan 1994); Russell Hardin, One for All 28-32 (Princeton 1995). A recent survey of this literature can be found in Lars Udéhn, Twenty-Five Years with The Logic of Collective Action, 36 Acta Sociologica 239 (1993).

${ }^{13}$ For a general discussion, see Hechter, Principles of Group Solidarity at 49-55 (cited in note 12). For a model discussing ostracism, see David Hirshleifer and Eric Rasmusen, Cooperation in a Repeated Prisoners' Dilemma with Ostracism, $12 \mathrm{~J}$ Econ Beh \& Org 87, 90103 (1989). 
counted by the expected cost of detection and punishment); in other words, cooperation is individually rational. ${ }^{14}$

An interesting literature discusses how people use organizational mechanisms to solve the prisoner's dilemma. This is somewhat tangential to the present topic, but a few points are worth noting. To maximize the likelihood of detecting cheaters, groups reduce the opportunities for private behavior (for example, with communal living), encourage confession, facilitate gossip ${ }^{15}$ and assign detection responsibilities to the most effective agents. ${ }^{16}$ To maximize the cost of being punished, groups create statusbased ranks, assign sanctioning responsibilities to the most effective agents, limit membership by ethnicity, isolate themselves geographically, require investment on entry, and prohibit extragroup affiliations. ${ }^{17}$ To evaluate defections properly, groups sometimes use formal, court-like means to resolve disputes; sometimes, they use informal means such as gossip and criticism. Importantly, to ensure solidarity, groups must maintain a size that produces an optimal mix of monitoring economies (which rise in small groups) and of resources (which rise in large

14 For example, an effective mechanism for deterring defection would, by penalizing defection with a fine of 3 , transform the prisoner's dilemma in note 9 into the following:

\begin{tabular}{l||c|c|c|}
\multicolumn{1}{c}{} & \multicolumn{1}{c}{ Cooperate } & Defect & Independent \\
\cline { 2 - 4 } Cooperate & 8,8 & 0,6 & \\
Defect & 6,0 & $-1,-1$ & \\
\cline { 2 - 4 } Independent & & & 6,6 \\
\hline
\end{tabular}

Cooperation now becomes the dominant strategy for both players. Given the expected payoff of 8 from cooperating, cooperation is preferable to both defection (where the payoffs would be 6 or -1 ) and independent action (where the payoff would be 6).

${ }^{15}$ See Sally Engle Merry, Rethinking Gossip and Scandal, in Donald Black, ed, 1 Toward a General Theory of Social Control 271, 284-86 (Academic 1984).

${ }^{16}$ See generally Hechter, Principles of Group Solidarity at 153-56 (cited in note 12) (discussing monitoring mechanisms).

17 Id at 150-67 (discussing status ranks and monitoring agents). See also Laurence $R$. Iannaccone, Sacrifice and Stigma: Reducing Free-Riding in Cults, Communes, and Other Collectives, $100 \mathrm{~J}$ Pol Econ 271, 274-76 (1992) (discussing controlling membership, isolating, and prohibiting affiliation). Communes exemplify how solidary groups maintain discipline through monitoring and sanctioning. See Rosabeth Moss Kanter, Commitment and Community: Communes and Utopias in Sociological Perspective 106-08 (Harvard 1972). Successful communes are more likely to create mechanisms for insulating members from the outside world, such as on-site services (medical clinics, for example), uniforms, foreign languages, restrictions on leaving the grounds, and rules for interaction with visitors. Id at 92. They are also more likely to create mechanisms for monitoring and sanctioning, such as regular confession, mutual and leader surveillance, and public denunciation of deviants. Id at 112. 
groups). ${ }^{18}$ Regardless of the importance of the cooperative benefits, groups do not survive if they do not use these mechanisms to solve basic problems of coordination.

Among the groups that do survive, some outlast others, in part because of differences in their capacities to absorb environmental shocks. ${ }^{19}$ A surge in unemployment, for example, destroys some unions but does not destroy others. This differential capacity comes from differences in members' incentives. In stable groups, the average payoff from cooperation greatly exceeds the average payoff from defection, so that relatively small decreases in the former or increases in the latter do not produce a breakdown of cooperation. In other words, the group's members face a large "cooperation-defection differential." A group's solidarity is a function of the members' cooperation-defection differentials. Everything else being equal, groups whose members face relatively large cooperation-defection differentials have more solidarity than groups whose members face relatively small differentials. Thus, when two groups face identical environmental fluctuations, the more solidary group will experience fewer defections, more loyalty, more stability, and more cooperation than the less solidary (or more "atomistic") group. ${ }^{20}$

$1 *$ See Robert Cooter and Janet T. Landa, Personal versus Impersonal Trade: The Size of Trading Groups and Contract Law, 4 Intl Rev L \& Econ 15, 17 (1984). See also Jack L. Carr and Janet T. Landa, The Economics of Symbols, Clan Names and Religion, $12 \mathrm{~J}$ Legal Stud 135, 139-42 (1983); Janet T. Landa, A Theory of the Ethnically Homogeneous Middleman Group: An Institutional Alternative to Contract Law, $10 \mathrm{~J}$ Legal Stud 349, 359-61 (1981) (pointing out that ethnically homogeneous middleman groups reduce transaction costs between members); Mark Casson, The Economics of Business Culture: Game Theory, Transaction Costs, and Economic Performance 169-85 (Clarendon 1991); David M. Kreps, Corporate Culture and Economic Theory, in James E. Alt and Kenneth A. Shepsle, eds, Perspectives on Positive Political Economy 90, 129-30 (1990) (As groups grow, and the range of unforeseen contingencies increases, group dispute resolution mechanisms become less effective.). Crowding also constrains membership size, as in the case of club goods. See James M. Buchanan, An Economic Theory of Clubs, 32 Economica 1, 3-6 (1965).

19 By "environmental shocks," I mean external events that modify the payoff matrix faced by group members.

${ }^{29}$ Consider the following matrix:

\begin{tabular}{l||c|c|c|}
\multicolumn{1}{c}{} & \multicolumn{1}{c}{ Cooperate } & Defect & \multicolumn{1}{c|}{ Independent } \\
\cline { 2 - 4 } Cooperate & $\mathrm{x}, \mathrm{y}$ & 0,6 & \\
\cline { 2 - 4 } Defect & 6,0 & $-1,-1$ & \\
\cline { 2 - 4 } Independent & & & 5,5 \\
\cline { 2 - 4 } & & &
\end{tabular}


It is the difference between the cooperation payoff and the defection payoff, not the absolute size of either, that motivates cooperation. Solidarity increases even when the payoff from cooperation declines, so long as the payoff from defection declines more rapidly. If an employer must pay union workers ten dollars per hour, the closest substitute nonunion wage falls from nine dollars per hour to eight dollars per hour, and (as is likely) the defection payoff varies with the nonunion wage, then the cooperation-defection differential for each worker-and, therefore, solidarity-has risen. Conversely, a decline in social hostility toward an ethnic or religious minority may decrease solidarity even if the cooperation payoff increases, because cooperation is no longer necessary to enable members of the minority to obtain goods and services that outsiders formerly denied to them (or supplied only at a premium). Even if the payoff from cooperation increases, solidarity declines so long as the payoff from defection increases at a greater rate. This important point will recur.

Summing up, in thinking about solidary groups it is useful to keep four propositions in mind. First, the cooperative surplus stimulates group creation and causes actors to abandon independent action. Actors obtain more benefits if cooperation succeeds than if it fails. ${ }^{21}$ Second, cooperation always involves costs, such as membership dues and other commitments to behave in privately costly ways (such as a commitment to participate in strikes). Third, cooperation depends on the success of mechanisms for detecting and punishing acts of free riding. Fourth, groups use a variety of sanctions to punish defectors. The operation of mechanisms to detect and punish free riding accounts for part of the cost of cooperation. For any given area of endeavor, cooperation is likely to displace independent action or defection when the cooperative surplus is high, the cooperation cost is low, the probability of being detected and sanctioned upon defection is high, and the severity of the sanction for defection is high. ${ }^{22}$

If $x=8$ and $y=8$, the cooperation-defection differential faced by each player is 2 . If $x=10$ and $y=9$, the cooperation-defection differentials are 4 and 3 . The differential measures the incentive to defect, given that the other party is expected to cooperate.

${ }^{21}$ I take no position on whether people enjoy cooperative behavior or solidarity for its own sake, and, thus, whether emotional fulfillment or some similar benefit should be counted as part of the surplus. Compare Norman Frohlich and Joe A. Oppenheimer, Choosing Justice: An Experimental Approach to Ethical Theory 183 (Califormia 1992) (suggesting that participation in decision making increases the willingness to cooperate).

${ }_{22}$ This approach is similar to Hechter, Principles of Group Solidarity at 49-55 (cited in note 12). 
A few examples, greatly simplified, illustrate this model's abstractness and applicability. Workers join unions because the increased wages and benefits resulting from unions' bargaining advantages exceed union dues and other cooperation costs. Unions expel and otherwise punish people who refuse to pay dues, march in picket lines, or engage in work slowdowns. People join religious associations because the collectivity allows them to obtain certain spiritual and material benefits that, even after subtracting cooperation costs (for example, tithes and contributions), exceed the benefits that the members could obtain alone. Religious associations scold, excommunicate, or at least fail to praise people who miss services, commit sins, and violate rituals. People form families because cooperation reduces the cost of running a household and raising children. Families sanction members who avoid chores or otherwise shirk responsibility. People join trade groups-collections of people who engage in repeat dealings with each other, as formal as trade associations and as informal as networks of continuing contractual relations-because the transactional economies that arise from repeat dealing exceed the costs of group coordination. Trade groups ostracize members who engage in unfair dealing. These illustrations show how, over a broad spectrum of action, different groups engaged in different enterprises manifest similar patterns of behavior identified by the model. ${ }^{23}$

This model's value for legal commentators lies in what it reveals about the law. By drawing attention to the conditions under which solidarity flourishes, it shows how the law affects groups' solidarity. As we shall see, different laws affect solidarity in different ways because they modify the cooperation-defection differentials in complex ways. The arguments are developed in Part II.

To simplify the later analysis, it is useful first to consider why states try to affect group behavior through law. Three answers suggest themselves. First, groups, because of the prisoner's dilemma, undersupply collective goods for their own members. A utility-maximizing state should enact laws that stimulate the supply of these goods, to the extent that the resulting increase in efficiency exceeds any inefficiencies caused by the state's actions. ${ }^{24}$ Second, groups often produce negative and positive

23 Part III discusses each of these examples at much greater length.

${ }^{24}$ It is possible for a solidary group to harm its members; this may occur, for example, when (1) the members are locked into a relationship that they cannot dissolve except 
externalities with respect to nonmembers. ${ }^{25}$ A state committed to utility maximization should use legal rules to promote group activities that produce positive externalities and to suppress group activities that produce negative externalities. Third, a state with any other goals-for example, income redistribution, enforcement of moral norms, transformation of individual preferences, maintenance of order, and so on-must account for the possibility that groups will react to legal changes in unintuitive ways, leading to perverse results. ${ }^{26}$

\section{LEGAL IMPLICATIONS OF GROUP SOLIDARITY}

This Part advances two main arguments about the interaction between the state (with its legal sanctions) and groups (with their nonlegal sanctions). Both arguments center on the methods the state uses to modify the cooperation-defection differentials faced by its citizens in different areas of life, and how these methods impact efficiency and wealth distribution.

Before turning to the arguments, however, we must develop a typology of rules. Three kinds of legal rules interest us. "Groupbased rules" transfer resources to (or from) groups in order to stimulate (or weaken) their ability to cooperate. "Category-based rules" transfer resources to (or from) the larger categories of people from which cooperative groups draw their members. "Dispute resolution rules" govern the resolution of disputes among group members. Group-based rules include, for example, laws

at great cost, or (2) information asymmetries, strategic behavior, or other market or cognitive failures prevent people from discovering the utility-decreasing nature of the group or from changing its organization. In particular, rules that govern group behavior often lag economic and technological change: outdated but entrenched customs cannot be overcome by the group's imperfect governance structures, but can be, sometimes, by the state. See Eric A. Posner, Law, Economics, and Inefficient Norms, $144 \mathrm{U} \mathrm{Pa} \mathrm{L}$ Rev (forthcoming 1996).

${ }^{25}$ Externalities are costs or benefits "that the voluntary actions of one or more people impose or confer on a third party or parties without their consent." Robert Cooter and Thomas Ulen, Law and Economics 45-46 (Scott, Foresman 1988). For example, the abovemarket wages produced by a successful union may lead to an increase in the prices of products. See text accompanying note 124 . Likewise, the union's various programs may bring stability to a community.

${ }_{26}$ Thus, this analysis does not presuppose a particular conception of social value. A group that produces collective goods for its members at the optimal level is a wealthmaximizing institution. Consequently, a wealth-maximizing court system might seek to mimic its rules, see Robert D. Cooter, Structural Adjudication and the New Law Merchant: A Model of Decentralized Law, 14 IntI Rev L \& Econ 215, 217 (1994), and a wealthmaximizing state might subsidize it. But, a state devoted to a broader conception of justice-however that term is defined-would choose to mimic or subsidize groups on the basis of their contribution to justice. 
that grant tax breaks, subsidies, and privileges to families, unions, religious associations, and political organizations, as well as laws that punish cartels and criminal conspiracies. Categorybased rules include laws that transfer resources to (or from) people, most obviously, on the basis of their race, sex, income level, and employment, but also, less obviously, on the basis of acts such as theft and tax evasion. Dispute resolution rules include the general principles of contract law (as applied to groups), as well as laws governing spousal abuse, discrimination by unions against their members, and conflicts that arise within religious congregations. This tripartite conception of legal rules permits the following arguments.

First, the state may modify the cooperation-defection differential in two ways: by transferring resources to (or from) the group itself; and by transferring resources to (or from) people who do not belong to the group but are in the category of people from which the group draws its members. Group-based rules, under certain conditions, increase (or reduce) the cooperation payoff without affecting the payoff from defection. Category-based rules, under certain conditions, indirectly increase (or reduce) the defection payoff without affecting the payoff from cooperation. However, neither group-based rules nor category-based rules necessarily change the group's solidarity level, as either kind of rule can raise or lower the payoffs from cooperation and defection by the same amount.

Second, the state may modify the cooperation-defection differential by facilitating or hindering the group's efforts to detect and punish defections. When the group's enforcement mechanisms are inferior to the court's, judicial dispute resolution rules that supplement those mechanisms increase the group's solidarity. However, when the group's enforcement mechanisms are superior to the court's, dispute resolution rules reduce solidarity. Assuming a goal of increasing solidarity, optimal judicial intervention involves balancing the imperfections of judicial enforcement against the imperfections of the group's enforcement mechanisms.

\section{A. Group-Based and Category-Based Rules}

Recall that a group's solidarity is a function of the cooperation-defection differential faced by each member. As the differential decreases, an environmental shock is more likely to create a prisoner's dilemma, causing the actors to defect or to revert to independent action. This Part examines how the state can use 
legal rules to affect the size of the cooperation-defection differential and, therefore, the solidarity of groups.

The problem is complex because any particular state action can simultaneously affect the value of cooperation, the value of defection, and the value of independent action in a variety of ways. For simplicity, we assume a case where a solidary group exists, that is, each player's cooperation-defection differential is greater than zero, and the value of cooperation exceeds the value of independent action for each player. The state can affect the differential by changing the value of cooperation, the value of defection, or both. The state can raise both values by the same amount; it can reduce both values by the same amount; it can raise one value more than the other; and it can reduce one value more than the other. For further simplicity, we focus on cases where state action either raises both values or raises one while holding the other constant. There are three interesting cases.

First, the state may seek to subsidize a group with a groupbased rule. Consider, for example, tax advantages and grants for unions, families, religious organizations, nonprofit organizations, and related groups; evidentiary, testamentary, and zoning privileges for families; bargaining and organizing privileges for unions; antitrust exemptions for certain business associations; and protections from discrimination for members of religious groups. One can understand these laws as attempts to raise the value of cooperation without also raising the value of defection.

Sometimes, such group-based rules increase the cooperationdefection differential. Consider the consequences of a tax break for a union. The union now has more money than it had before. It may use this extra money to improve record keeping and other forms of monitoring, thereby increasing the probability of detecting defectors and reducing the expected gain from defection. As a result, the cooperation-defection differential increases, and so does solidarity. The defection rate declines and the size of the surplus increases. ${ }^{27}$

By contrast, the same rule would not affect the differential if the individual obtained his share of the increased cooperative surplus whether or not he defected. Suppose the union uses its tax break to reduce dues by, say, ten dollars. This makes both

${ }^{27}$ Consider the matrix in note 9 . If the tax break raised the payoff from cooperation by 2 (to 10), the parties would choose cooperation (union formation) over independent action (where the payoff would be 6) at stage 1 , and cooperation over defection (where the payoff would be 9 or 2) at stage 2 . 
cooperating with a union ten dollars more valuable and defecting (by, for example, crossing a picket line) ten dollars more valuable, since one obtains the ten-dollar benefit (the dues reduction) in either event. Therefore, neither the cooperation-defection differential nor the solidarity level changes. ${ }^{28}$

As an aside, note that the state has two strategies for subsidizing a group. The tax break example illustrates a subsidy to the group's agent (presumably, its leaders). By contrast, allowing the union members a tax deduction for their dues exemplifies a subsidy to the cooperating actors. If the group is sufficiently solidary, the mode of transfer makes no difference, as the group will redistribute resources in an optimal fashion among members or functions. The union could increase its dues by an amount that offsets the members' tax break in order to effect a transfer to its coffers. Where friction exists between the members and the leadership, however, the transfer's efficiency depends on whether group leaders generally act in the members' interests (in which case the state should effect the transfer to the group as agency) or generally do not (in which case the state should effect the transfer to the members). ${ }^{29}$

Even a subsidy that successfully increases the value of the differential in the short term may sometimes have perverse results in the long term. For example, if a group cannot restrict membership, the subsidy will produce an increase in membership that may offset the increase in solidarity. ${ }^{30} \mathrm{Or}$, if the subsidy is available to multiple groups, intergroup competition for members may offset any increase in solidarity. ${ }^{31}$

The second interesting case occurs when the state seeks to help a category of people through category-based rules. Consider welfare laws that transfer money to poor people, antidiscrimination laws that transfer power or wealth to minorities, and employment laws that transfer resources to employees.

${ }^{28}$ One might wonder why the union would do this. Presumably, it would do so only if it is poorly run, or if it already supplies the level of surplus that is optimal for the members. Part III.B analyzes this question in greater detail.

2 Compare Shelly Lundberg and Robert A. Pollak, Separate Spheres Bargaining and the Marriage Market, $101 \mathrm{~J}$ Pol Econ 988, 998 (1993) (Child care subsidies issued to the mother and child care subsidies issued to the father may, in the short run, produce different distributions of wealth within a marriage.).

3a In the long term, the increased membership drives up the cost of monitoring, thereby reducing the cooperation-defection differential. For further discussion, see Part II.C.

31 For a discussion of the problems arising from intergroup competition, see Part II.C. 
In these cases, the state intends to raise the value of independent action without also raising the value of cooperation.

Under certain conditions, category-based rules reduce the cooperation-defection differential. A category-based rule, unlike a group-based rule, makes defection (as well as independent action) relatively more attractive, without necessarily increasing the value of cooperation. For example, an antidiscrimination law could increase the value of defection from a solidary ethnically based economic group such as the kye (because a member has less to lose from expulsion) without increasing the value of cooperation. The member has less to lose from expulsion and less to gain from membership because the market now supplies the credit for which he formerly depended on the group. Because the cooperation-defection differential declines, so does the group's solidarity, and its collective good is diminished. ${ }^{32}$

However, category-based rules sometimes have no effect on the cooperation-defection differential or even increase it. Suppose, for example, that the state makes a one-time transfer of one hundred dollars to all minorities. This transfer would not affect the solidarity of kyes, because it would increase the value of cooperating and free riding by the same amount. ${ }^{33} \mathrm{Or}$, suppose that the state provides free education to all minorities. This transfer could increase the solidarity of kyes by providing a good that complements the collective good already produced by the kyes. People with better educations, the story goes, operate a kye more efficiently than people with worse educations. ${ }^{34}$ But this kind of story is strained, and the effect is surely rare. Because well educated Koreans would be able to interact easily with out-

32 Consider the following matrix:

\begin{tabular}{l||c|c|c|} 
Cooperate & \multicolumn{1}{c}{ Cooperate } & Defect & Independent \\
\cline { 2 - 4 } & 10,10 & 0,9 & \\
Defect & 9,0 & 2,2 & \\
Independent & & & 6,6 \\
\hline
\end{tabular}

If a category-based rule increased the payoff from defection (and, one would assume, the value of independent action) by 2 (for defection, from 9 or 2 to 11 or 4 ), the categorybased rule would create a prisoner's dilemma, thereby causing the parties to defect and the group to dissolve. As a result, the joint outcome falls from 20 to 16.

33 This assumes that there are no income effects.

${ }^{34}$ Similarly, an antidiscrimination law could increase the cooperative surplus of the kye by giving members more valuable opportunities to exploit, or by allowing the kye to interact with banks and other actors. 
side institutions, they would not have to depend on the kye, and solidarity would probably decline.

We can restate this point in the following way. The state uses category-based rules to produce collective goods, just as a group uses its own rules to produce collective goods. When the state produces a collective good that overlaps with a group's collective good, the interaction will produce one of three possible kinds of results. First, the state's collective good might be a substitute for the group's collective good, as when welfare or antidiscrimination laws enable members independently to obtain services that the group would otherwise provide. ${ }^{35}$ Second, the state's collective good might be a complement of the group's collective good, as when an education law enables members to produce their collective goods more efficiently. Third, the state's collective good might not affect the group's collective good at all, as in the example of the one-hundred-dollar transfer. Only in the first case-where the state's collective good is a substitute for the group's-do category-based rules reduce solidarity and, therefore, reduce the value of the group's collective good.

The third interesting case occurs when the state simultaneously uses group-based and category-based rules to affect both a category of people and groups within that category. In this case, the rules may work at cross purposes. Suppose, for example, that the state both subsidizes kyes and enacts a new antidiscrimination law, or both subsidizes unions and increases employment law protections. Under plausible conditions, the group-based transfer strengthens the group's solidarity, while the category-based transfer weakens it. If these conditions obtain, the combined use of group-based subsidies and category-based transfers has no effect or an indeterminate effect on the solidarity of groups, but possibly even reduces their solidarity. To be sure, if the state transfers more to the group than to the category, or vice versa, the stronger rule will dominate the weaker rule.

In sum, a group-based rule that subsidizes a group either increases or does not affect the group's solidarity, depending on the extent to which the group uses the subsidy to improve its self-governance structures. A category-based rule that transfers

35 The analysis is the same whether the state intervenes to correct a market failure or to engage in redistribution. An efficient market has the same capacity to undermine solidary groups as the state does. See Hechter, Principles of Group Solidarity at 177 (cited in note 12). When state intervention solves a market failure, the availability of cheaper goods may eliminate the cooperation-defection differential without making independent action more valuable than collective action. 
resources to a category ordinarily reduces or has no effect on, but in rare cases increases, the solidarity of a group consisting of a subset of that category. The result depends on the relationship between the collective good produced by the group and the collective good produced by the category-based rule. ${ }^{36}$ The combined use of a group-based rule and a category-based rule, where the group is a subset of the category and the transfers are of similar magnitudes, has either no effect or an indeterminate effect on the group's solidarity.

\section{Efficiency effects.}

As the prisoner's dilemma illustrates, individuals fail to obtain a potential cooperative surplus where, whether the other person cooperates or not, the value of free riding for any person exceeds the value of cooperating. ${ }^{37}$ The failure to cooperate results in an efficiency loss to the individuals, represented by the difference between the joint value of cooperation and the joint value of independent action. If the group does not produce a negative externality, the efficiency loss is also a loss to society. ${ }^{38}$ The state can potentially reduce this efficiency loss-that is, solve the prisoner's dilemma-through appropriate intervention.

The efficiency effects of group-based and category-based rules depend on a variety of factors, but one can make the following generalizations.

First, a group-based subsidy increases efficiency if, by reducing defection, it increases the value of the collective good by an amount greater than any collateral efficiency losses resulting from the taxation and administration necessary to effect the subsidy. ${ }^{39}$ Conversely, a group-based penalty, under similar con-

${ }^{36}$ Group-based rules and category-based rules that transferred resources away from the group or the category would have the opposite effects.

${ }_{37}$ The prisoner's dilemma implies that, for example, ethnically based trade groups undersupply dispute resolution, families undersupply household production, unions undersupply bargaining power, and religious groups undersupply spiritual benefits.

${ }^{33}$ If the group did produce a negative externality, then the efficiency loss associated with the lost surplus is offset to the extent of the foregone negative externality.

${ }^{39}$ Consider the following matrix:

\begin{tabular}{l||c|c|c|}
\multicolumn{1}{c}{} & \multicolumn{1}{c}{ Cooperate } & Defect & Independent \\
\cline { 2 - 4 } $\begin{array}{l}\text { Cooperate } \\
\text { Defect }\end{array}$ & 8,8 & 0,9 & \\
\cline { 2 - 4 } Independent & 9,0 & 2,2 & \\
\cline { 2 - 4 } & & & 6,6 \\
\hline \multicolumn{3}{|c|}{ HeinOnline -- 63 U. Chi. L. Rev. 150 1996 }
\end{tabular}


ditions, reduces efficiency. Finally, when a group-based subsidy or penalty raises or lowers both the value of cooperation and the value of defection, without affecting the differential, it produces no efficiency change except for the loss resulting from the administrative costs of the transfer.

Second, a category-based transfer in favor of a category of people reduces efficiency if it reduces the cooperation-defection differential by an amount sufficient, everything else being equal, to increase defections. ${ }^{40}$ Conversely, a category-based transfer away from a category, under similar conditions, increases efficiency by reducing defections. But these effects must be balanced against any other efficiency effects produced by the categorybased transfer. For example, if antidiscrimination laws produce efficiency gains by increasing the pool of possible employees, ${ }^{41}$ this gain would at least partly offset, and perhaps more than offset, any efficiency loss resulting from the laws' subversion of ethnically based cooperative groups.

A group-based transfer of 2 to each party, conditioned on cooperation, would cause cooperation. The parties' joint wealth would rise by 8 , from 12 to 20 . Because the state took 4 away from taxpayers to support the group-based transfer, the net increase in social wealth is 4 , excluding the transfer's administrative cost and the cost produced by taxinduced distortions; therefore, wealth increases, and the transfer is efficient, as long as these costs equal an amount less than 4 .

40 Consider the following matrix:

\begin{tabular}{l||c|c|c|}
\multicolumn{1}{c}{} & \multicolumn{1}{c}{ Cooperate } & Defect & \multicolumn{1}{c}{ Independent } \\
\cline { 2 - 4 } Cooperate & 10,10 & 0,9 & \\
\cline { 2 - 4 } Defect & 9,0 & 2,2 & \\
\cline { 2 - 4 } Independent & & & 6,6 \\
\cline { 2 - 4 } & & &
\end{tabular}

A category-based transfer to each party, that is worth 2 but only if the parties do not cooperate, would raise each party's payoffs from defection to 11 and 4 , and the payoff from independent action to 8 . As this would cause the parties to shift from cooperation to independent action (neither will cooperate because both know that the other will defect), their joint wealth would fall from 20 to 16 .

Whether a defector can obtain a transfer conditioned on noncooperation depends on the nature of the transfer. For example, by providing insurance against financial misfortune, welfare benefits the member of the mutual aid group who is simultaneously defecting by (secretly) not paying his dues. The transfer increases the incentive to defect because the consequences of expulsion are less severe. However, if welfare is limited to people not currently or formerly in mutual aid groups, then the transfer does not increase the value of defection, and cooperation will still result.

11 See John J. Donohue III, Is Title VII Efficient?, 134 U Pa L Rev 1411, 1429 (1986). For another theory, see Richard H. McAdams, Cooperation and Conflict: The Economics of Group Status Production and Race Discrimination, 108 Harv L Rev 1003, 1078-82 (1995). 
Third, combined use of group-based transfers to groups and category-based transfers to a category from which the group draws its members is unlikely to promote efficiency, compared to the use of just one kind of transfer. Suppose that a group-based subsidy alone would increase efficiency by promoting the solidarity of an efficient group. Then, the category-based rule, by reducing that group's solidarity, reduces efficiency. Now suppose that a category-based rule alone would increase efficiency by solving some market failure. Then, the group-based rule, by enabling members of the category to form groups that insulate themselves from the category-based rule, reduces efficiency. ${ }^{42}$ When the state transfers wealth both to groups and to the categories that contain them, it undermines its own actions and incurs administrative costs without changing behavior in the desired way.

Fourth, group-based subsidies and category-based penalties can increase the utility of nonmembers when groups produce positive externalities. For example, subsidization of charitable religious groups stimulates them to increase the amount of charitable relief that they provide to the general public. However, this means of preventing groups from undersupplying positive externalities faces a complication. Even if the state can increase the cooperation-defection differential (by subsidizing group action or penalizing defection or independent action), it does not follow that the externality's size will increase. If the members seek only a certain level of collective benefit, and are already producing that benefit, then the subsidy, by increasing the benefit level, may cause them to reduce their level of cooperation so that they produce only the originally desired amount. As a result, the increase in the collective good's value is less than the value of the subsidy. ${ }^{43}$ In this case, a transfer designed to increase a group's supply of a positive externality only redistributes wealth to the group's members.

42 Suppose, for example, that a category-based employment rule produces an efficient labor market, and that the state also promotes unions with group-based transfers. If all employees unionize and negotiate their own contracts with employers, these contracts produce a market that is either less efficient than or equally efficient as the market that would exist under a pure category-based regulation. Even in the best case, the combined regulation creates duplicative administrative costs without producing any gains.

43 For a discussion and qualifications, see Theodore Bergstrom, Lawrence Blume, and Hal Varian, On the Private Provision of Public Goods, 29 J Pub Econ 25, 42-43 (1986). 
2. Distributional effects.

Distributional effects are important when the state seeks to regulate groups in a way that transfers wealth or power to a certain category of people, such as the poor, an ethnic minority, unskilled laborers, or inhabitants of a certain region of the country. Under the group-based approach, the state transfers wealth to a group with the expectation that the group will efficiently distribute the wealth among its members (or even among nonmembers). Under the category-based approach, the state transfers wealth or power directly to everyone in a given category.

For example, the state might alleviate poverty not (or not only) by transferring wealth to all poor people, but also by transferring wealth to religious groups, ethnic trading groups, and other cooperative associations whose members are poor. Or, it might assist members of an ethnic category not (or not only) by enacting laws that protect them against discrimination, but also by transferring power to ethnically based groups that provide them with economic and social opportunities.

The advantage of group-based transfers is that they allow the state to free ride on the group's independent efforts to benefit its members. The group's superior informational and social networks allow it to distribute wealth with greater precision than the state's bureaucracy. This not only minimizes the transfer of wealth to the nonpoor, but also deters the antisocial behavior that transfers otherwise stimulate. ${ }^{44}$ Moreover, if the transfer increases the group's efficiency and solidarity, along the lines suggested above, it also reduces the incidence of ostracism in the sympathetic category. A more solidary group by definition suffers less defection than a less solidary one. The subsidized group ostracizes fewer people and, therefore, fewer people will lose the benefits of membership.

The disadvantage of group-based transfers lies in the state's limited control over a solidary group. Transfers sometimes strengthen groups that have disagreeable norms, such as racist groups. Moreover, although a transfer is likely to redistribute more wealth to insiders than to people whom the group has ostracized, the ostracized people may be in greater need precisely because they lack the group's protection. Thus, even though

4 See Eric A. Posner, Contract Law in the Welfare State: A Defense of the Unconscionability Doctrine, Usury Laws, and Related Limitations on the Freedom to Contract, $24 \mathrm{~J}$ Legal Stud 283, 288-89 (1995) (discussing some of the perverse incentives created by welfare). 
group-based rules might equalize wealth among people inside and outside a particular category, they can also cause greater wealth inequality within the category. Such an effect is likely when the group-based rule transfers wealth to groups within an ethnic category characterized by larger numbers of more solidary groups, rather than in an ethnic category characterized by smaller numbers of less solidary groups. If policymakers are concerned with the well-being of nonmembers of the relevant groups, then group-based rules remain troublesome.

At first glance, this phenomenon suggests that the optimal approach to wealth redistribution would involve a combination of group-based and category-based transfers. The state could, for example, subsidize kyes, on the theory that these institutions are powerful and efficient engines for advancing the interests of Korean-Americans, while also transferring wealth to Korean-Americans generally in order to ensure that those who do not belong to kyes maintain an adequate standard of living.

However, as we have seen, these approaches are in tension. If the state transfers wealth to a group (for example, only those Korean immigrants who cooperate in kyes), it strengthens the group at the expense of nonmembers. If, at the same time, the state makes category-based transfers (for example, to all Korean immigrants), it weakens the group. Taking both approaches simultaneously produces an indeterminate effect, as the reduction in the cooperation-defection differential caused by the categorybased transfer offsets the increase caused by the group-based transfer. Either the group is made better off and the ostracized insiders are made worse off, or the category is made better off at the expense of the group. Ironically, when simultaneously using both approaches reduces the values of the cooperative surpluses more than it increases the wealth of the category, the aggregate is worse off than before. ${ }^{45}$

In light of this problem, one might conclude that the optimal approach to redistributing wealth involves group-based rules for

45 For example, consider a category consisting of some people who face the payoffs described in the matrix in note 9 and of others who face the payoffs described in the matrix in note 40 . If the state transfers 1 to every person who participates in a group and 3 to every person who does not participate, each party facing the payoffs in the first matrix would gain by 3 (they continue to engage in independent action), while each party facing the payoffs in the second matrix would lose by 1 (their groups dissolve). Thus, if, prior to the state action, more than three times as many people had been participating in groups as had not, the state action, though intended to benefit everyone, reduces the aggregate wealth of the category. 
relatively solidary groups with inoffensive and redistributional norms, and category-based rules elsewhere. Part III illustrates this argument by contrasting labor and employment law, subsidization of religious groups and of families and welfare law, and trade group subsidies and antidiscrimination law. These case studies show that the state can mitigate the tension between the group-based and category-based approaches by picking the approach more suited to the particular social and economic conditions at hand.

\section{B. Intervening in Disputes Within Groups}

When people contract with each other they face two kinds of risks: (1) that an unforeseen or unlikely contingency will make performance unprofitable to one or both parties, and (2) that one party will act opportunistically in a way technically consistent with the contract but unprofitable to the other party. Parties can protect themselves by hiring lawyers to draft detailed contracts, posting bonds and other forms of security, limiting the size of their investments, and by trusting courts, despite their various limitations, to fill gaps in contracts and punish opportunism after the fact. But these precautions and risks are themselves costly, and the uncertainties involved in dealing with strangers make contracting expensive.

When members of a solidary group transact, norms and nonlegal sanctions generally resolve disputes. When contingencies arise, norms allocate risks and specify means of resolution. Norms also prohibit bad faith and opportunism. The importance of maintaining a good reputation and of avoiding ostracism deters improper behavior. Accordingly, insiders can dispense with expensive formalities-lawyers, bonds, even writings-and with the unreliable courts. ${ }^{46}$

While it might seem to follow that courts should defer to group resolution of disputes whenever possible, this intuition is false. Suppose, for the moment, that courts should treat all private agreements, whether between strangers or between mem-

${ }^{45}$ For a model showing the conditions under which reputational concerns ensure optimal contractual behavior, see Lewis A. Kornhauser, Reliance, Reputation, and Breach of Contract, $26 \mathrm{~J} \mathrm{~L} \&$ Econ 691, 699-703 (1983). See also Benjamin Klein and Keith B. Leffler, The Role of Market Forces in Assuring Contractual Performance, $89 \mathrm{~J}$ Pol Econ 615, 621 (1981); Kreps, Corporate Culture and Economic Theory at 100-11 (cited in note 18); L.G. Telser, A Theory of Self-Enforcing Agreements, 53 J Bus 27, 37 (1980); Jonathan M. Karpoff and John R. Lott, Jr., The Reputational Penalty Firms Bear from Committing Criminal Fraud, 36 J L \& Econ 757, 780-89 (1993). 
bers of a group, in a manner that maximizes their ex ante value. If courts enforced contracts perfectly and costlessly, they should resolve any dispute, whether arising between strangers or within a solidary group, and one would expect all parties to seek a reme$d y$ in the courts. If courts resolved disputes perfectly and costlessly, they would allocate risks and deter opportunism in such a way that maximized the ex ante value of whatever enterprise the strangers or the members of the group had chosen to undertake.

However, because courts are costly and error prone, they should defer to other dispute resolution mechanisms when those mechanisms provide better ex ante incentives to cooperate. ${ }^{47}$ In the polar case of a contract dispute between complete strangers, generally no plausible alternative dispute resolution mechanism exists. As long as the courts' costly and error-prone enforcement is superior to no enforcement, as would usually be the case, the courts should intervene by hearing the case and deciding on the merits whether one party violated the terms of the contract. ${ }^{48}$

By contrast, when a dispute arises between members of a highly solidary group, the group's enforcement mechanism will likely be superior to that of the courts. Most groups have intimate knowledge about their own norms and about the facts underlying the dispute. Under the pressure of the market, these groups have also likely developed effective mechanisms for gathering information and resolving disputes. In comparison to the wealth of detail at the groups' disposal, judges and juries are generally ignorant. Groups' superior information-gathering and dispute-resolution abilities help explain the widespread, powerful norms against taking disputes to courts. Referring to these advantages, some commentators argue that courts should defer to the norms of groups. ${ }^{49}$

However, this story overlooks two complications. First, even error-prone courts can, under certain conditions, provide optimal

47 Other dispute resolution mechanisms may be more efficient than the courts because such mechanisms make fewer errors at the same cost, or the same errors at lower cost. I ignore the problem that parties are likely to prefer courts because states subsidize them. Thus, even if courts make more errors at higher cost than private alternatives, parties will prefer them so long as the subsidy offsets these losses. This problem provides further support for judicial nonintervention in disputes arising within solidary groups.

43 Sometimes, even error-prone judicial enforcement can produce optimal incentives. See Gillian K. Hadfield, Judicial Competence and the Interpretation of Incomplete Contracts, 23 J Legal Stud 159, 174 (1994).

${ }_{49}$ See Ellickson, Order Without Law at 254-55, 283-86 (cited in note 5) (describing when courts should and should not defer). 
incentives to cooperate (that is, not to cheat on the contract). This result varies with such factors as the parties' ability to structure a contract so as to minimize the risk of dispute. ${ }^{50}$ Consequently, it is possible that although the court resolves a particular kind of dispute less competently than the group, the court's less competent ex post decisions produce better ex ante incentives to cooperate. The importance of this phenomenon, however, is surely limited. Even when an error-prone court produces optimal or good incentives, the (less) error-prone group still may do the same (because of the same phenomenon). Therefore, courts should generally defer. Moreover, groups that recognize this phenomenon will allow members to bring disputes to court in those unusual cases in which courts do a better job. ${ }^{51}$

Second, although solidary groups obtain and process most kinds of information more effectively than courts, their nonlegal sanctions are sometimes less powerful than the courts' legal sanctions. As a result, when the value of opportunism exceeds a certain threshold ("high-stakes opportunism"), the opportunist prefers cheating, even if it visits upon him the group's harshest sanctions (such as ostracism), perhaps taking the money and moving to a jurisdiction where the solidary group has no influence. By contrast, the courts' ability to reach distant jurisdictions and force wrongdoers to disgorge their wrongful gains deters such high-stakes opportunism even when the group's nonlegal sanctions do not. Accordingly, against the group's informational advantages, the courts often have sanctioning advantages. ${ }^{52}$

Thus, the desirability of judicial intervention depends both on the efficiency of the group's detection and sanctioning mechanism and on the value of a defector's opportunity. As the quality of the mechanism declines and the value of the opportunity rises, judicial intervention becomes more likely to provide superior incentives to cooperate. In cases of sufficiently high-value defection and low-level solidarity, the group cannot deter the defection

5 See Hadfield, $23 \mathrm{~J}$ Legal Stud at 180-83 (cited in note 48).

51 For example, the diamond group allows members to sue each other over patent infringement (as opposed to contract disputes), presumably because it believes patent courts can resolve the disputes more accurately than it can. See Lisa Bernstein, Opting Out of the Legal System: Extralegal Contractual Relations in the Diamond Industry, $21 \mathrm{~J}$ Legal Stud 115, 126-27 \& n 26 (1992), citing Leon Finker, Inc. v Schlussel, 469 F Supp 674 (S D NY 1979).

52 This tradeoff is stylized. As the diamond group example discussed in the previous note illustrates, sometimes groups have worse information about norms than do courts. In addition, sometimes groups have stronger sanctions than those available to the courts. For example, people sometimes commit suicide after being ostracized from a group. 
anyway. The courts' (often) superior sanctioning mechanisms may provide an adequate resolution, even if the courts' (usual) informational disadvantages prevent a perfect one. By contrast, in cases of relatively low-value defections from groups with relatively high levels of solidarity, the courts' superior sanctions are unnecessary, and their informational disadvantages are important. Accordingly, in such cases, they should defer to the group. ${ }^{53}$

As a general rule, when one member of a group sues another, or when the leader, representing the group, sues a member, or when a member sues the leader, a court should hear the case if the dispute involves high-value stakes within a low-solidarity group. Otherwise, it should dismiss. The fact that a group or its leader brings a suit does not mean that the suit maximizes that group's ex ante value. A leader can behave opportunistically with respect to followers in the same way that a member can behave opportunistically with respect to the group.

As a practical matter, how does the court decide that the stakes are sufficiently large and the group sufficiently atomistic to justify intervention? The court might start by asking (1) would the members of the group have agreed ex ante that a court should resolve this dispute, and, if so, (2) what is the proper allocation of obligations, according to hypothetical consent or some other norm of contract law. But this heuristic would not get the court very far. No such agreement would likely appear on paper, and, although groups sometimes have norms permitting lawsuits for some kinds of disputes, they rarely articulate these norms in a way that is accessible to courts. ${ }^{54}$

A more promising approach requires courts to look at the two relevant factors: the solidarity of the group and the value of defection. Indicia of solidarity include the frequency with which members bring disputes to court, the homogeneity of the members' interests, the homogeneity of the members' back-

53 Robert Cooter argues that courts should enforce the customs or norms of groups that do not harm their members or produce negative externalities. See Cooter, 14 Intl Rev L \& Econ at 226-27 (cited in note 26). However, this must be qualified to take account of groups' often superior enforcement mechanisms. The courts should refuse to enforce the customs or norms, except when the stakes are sufficiently high.

54 See note 116. Courts have long refused to enforce promises that the parties clearly did not intend to be legally enforceable. See Panto v Moore Business Forms, Inc., $130 \mathrm{NH}$ 730, 547 A2d 260, 268 (1988) (Souter) (An employer can escape liability "by announcing in the written policy [in the employment contract] that it was not an offer, or a policy enforceable as a contractual obligation."). Compare McDonald v Mobile Coal Producing, Inc., 820 P2d 986, 989 (Wyo 1991) (handbook disclaimers too inconspicuous to be binding). 
grounds, the effectiveness of the group's sanctioning mechanisms, the isolation of the group, the value of nongroup activity to members, and the extent to which the group satisfies most of the members' needs and desires. ${ }^{55}$ The value of the opportunistic act is likely to be "high" if changes in the environment have caused a radical change in the difference between the values of cooperation and of defection or independent action. ${ }^{56}$

Evaluating these factors involves a difficult interpretative inquiry. But the necessary distinctions are no more difficult to make than they are in other areas of the law. To illustrate, contrast a dispute between kye members over collateral requirements in the ordinary course of business, and the same dispute arising in the aftermath of a riot; ${ }^{57}$ a dispute between a seller and buyer with continuing dealings over the quality of some goods, and a dispute over the termination of a franchise; $;^{58}$ a complaint in a union against a person who does not pay his dues, and a complaint against a person who does not join a strike; ostracism from a religious sect, and a schism in a congregation; a battle over the allocation of household chores within a marriage, and a battle over the allocation of property after it dissolves. In each pair, as Part III discusses, low-stakes opportunism within a highly solidary group occurs-and counsels against judicial intervention-in the first instance, and not in the second. ${ }^{59}$

In sum, wealth-maximizing courts should defer to groups' resolutions of internal disputes, just as courts in the administra-

5s See note 17; Hechter, Principles of Group Solidarity at 150-67 (cited in note 12). A sociological study provides many examples from day-to-day life in a steel mill town. See William Kornblum, Blue Collar Community 36-37 (Chicago 1974).

is The economic literature on relational contracts overlooks the importance of the trading group to which relational contracting partners belong, the distinction between high-value opportunism and low-value opportunism, and the relation between the solidarity of the group and the value of the opportunistic act. For example, Goetz and Scott, while recognizing the importance of nonlegal sanctions, do not suggest that courts should try to analyze their strength and relevance in particular disputes. See Charles J. Goetz and Robert E. Scott, Principles of Relational Contracts, 67 Va L Rev 1089, 1148 (1981).

57 See note 119 and accompanying text.

s See Macaulay, $28 \mathrm{Am}$ Soc Rev at 65-66 (cited in note 2).

59 Compare Charny, 104 Harv L Rev at 447-51 (cited in note 5); Robert E. Scott, Conflict and Cooperation in Long-Term Contracts, 75 Cal L Rev 2005, 2039-46 (1987) (enforcement mechanisms). See also Macneil's analysis of relational contracts, Ian $\mathrm{R}$. Macneil, The New Social Contract: An Inquiry into Modern Contractual Relations 64-117 (Yale 1980), and Williamson's transaction cost economics, Oliver E. Williamson, The Economic Institutions of Capitalism: Firms, Markets, Relational Contracting 20-21, 164-66 (Free Press 1985). Compare also Oliver E. Williamson, Economic Institutions: Spontaneous and Intentional Governance, $7 \mathrm{~J} \mathrm{~L}$ Econ \& Org 159, 164-65 (Special Issue 1991) (discussing why courts do not resolve disputes between components of a corporation). 
tive law context defer to agency determinations. ${ }^{60}$ Normatively, such a deferential attitude simplifies the courts' task, while improving their accuracy. A deference principle frees the courts from having to resolve the merits of disputes once they make the preliminary determination that a dispute involves low stakes within a highly solidary group. ${ }^{61}$ As a descriptive matter, Part III argues, certain areas of the law already incorporate this approach.

In the case of groups that engage in undesirable behavior, however, courts should not use legal sanctions to promote solidarity. Courts should instead interfere so as to inhibit the group's undesirable norms. Examples of such interference include laws preventing abuse within families, discrimination within unions, and punishment of cheaters in price-fixing schemes operated by trade groups. ${ }^{62}$ Indeed, the state might direct courts to use rules to redistribute wealth among group members-from husbands to wives, for example, or among workers in a union. But, if the group is sufficiently solidary, using legal sanctions to interfere with its norms is unlikely to redistribute wealth. The group will merely transfer other resources away from benefitted parties to the other members. ${ }^{63}$

Conclusion: Implications for Contract Law. Over the last decade, scholars, applying increasingly rigorous economic methods to the problems of contract law, have generated extremely

60 This deferential attitude serves as a contractual principle, a kind of default rule for resolving disputes. Insofar as this rule maximizes a group's solidarity, its implementation in place of some other background rule serves as a group-based advantage. By contrast, a dispute resolution rule under which courts intervened for the sake of some ideal or purpose other than maximization of solidarity-for example, to protect spouses against abuse or union members against discrimination-would be a category-based transfer: such a rule would transfer wealth to a particular category of people (abused spouses or disadvantaged union members).

${ }_{61}$ Again, this point requires qualification. Error-prone courts could, in some cases, resolve low-value disputes within highly solidary groups more effectively than could the more competent group, because of the incentives produced by legal uncertainty. See text accompanying notes 66-67. Further study is needed to resolve this point.

62 Consider the case of Dawson v Hillsborough County, Florida School Board, 322 F Supp 286, 304 (M D Fla 1971), where the court struck down a school district's hair-length code. Compare the court's argument that the code is intolerable because the short-hair norm does not promote the board's educational goals, id at 298-303, and the argument that the code is intolerable because it interferes with privacy rights, id at 303-04. The former argument is less convincing than the latter, in large part because the court seems less competent at evaluating whether a norm supports a group's goal than whether it is consistent with the law.

E3 Compare Bergstrom, Blume, and Varian, $29 \mathrm{~J}$ Pub Econ at 35-37 (cited in note 43). For further discussion, see text accompanying note 43. 
complicated optimal rules. On the whole, this line of scholarship suggests that courts cannot deter suboptimal behavior very effectively. ${ }^{64}$ These results must be compared with the result that a no-damage rule is optimal if nonlegal sanctions deter opportunistic behavior. ${ }^{65}$

This comparison suggests that (1) optimal contract rules must be much simpler than the articles suggest, and (2) such rules must discourage courts from intervening in disputes when alternative dispute resolution mechanisms would be superior, especially when the complexity of apparently ideal rules generates overwhelming uncertainty. Some work does deal with the problems caused by the uncertainty of legal rules. ${ }^{66}$ Some work even addresses the question whether courts should refuse to intervene in disputes because of the uncertainty inherent in legal rules, although this work typically compares uncertain judicial enforcement with nonenforcement. ${ }^{67}$ However, as far as I know, no one has attempted to compare judicial enforcement with group enforcement in an effort to specify the conditions under which courts should refuse to intervene in contract disputes in order to encourage reliance on more efficient, group-run dispute resolution mechanisms. ${ }^{68}$

\section{A Note on Conflict Between Groups}

Individuals are members of more than one solidary group at the same time. A woman may simultaneously be a member of the family in which she is the wife and mother, the family in which she is a daughter, a voluntary neighborhood association, a network of friends, a church, a union local, and a work group. Each group provides characteristic but overlapping benefits. Each

is See, for example, Jason Scott Johnston, Strategic Bargaining and the Economic Theory of Contract Default Rules, 100 Yale L J 615, 626-39 (1990) (on strategic incentives); Ian Ayres and Robert Gertner, Strategic Contractual Inefficiency and the Optimal Choice of Legal Rules, 101 Yale L J 729, 735-62 (1992) (same); Alan Schwartz, Relational Contracts in the Courts: An Analysis of Incomplete Agreements and Judicial Strategies, 21 J Legal Stud 271, 289-90 (1992) (long-term contracts).

s See Kornhauser, $26 \mathrm{~J} \mathrm{~L} \&$ Econ at 703 (cited in note 46).

6o See Hadfield, $23 \mathrm{~J}$ Legal Stud at 175-80 (cited in note 48); Schwartz, $21 \mathrm{~J}$ Legal Stud at 314 (cited in note 64); Richard Craswell and John E. Calfee, Deterrence and Uncertain Legal Standards, 2 J L Econ \& Org 279, 283-92 (1986) (discussing the deterrent effects of the uncertainty of tort enforcement); Jason S. Johnston, Punitive Liability: A New Paradigm of Efficiency in Tort Law, 87 Colum L Rev 1385, 1392-95 (1987) (underdeterrent and overdeterrent effects of legal rules).

57 See Hadfield, $23 \mathrm{~J}$ Legal Stud at 159 (cited in note 48 ).

es However, the comparative approach of Williamson and his followers has some similarities. See note 59. 
group demands loyalty, imposes its own obligations, and applies its own nonlegal sanctions. Tensions arise, but so do synergies.

Tensions arise because groups demand different kinds of behavior and impose conflicting nonlegal sanctions. A person's friends, coworkers, and family all bid for his time and resources by offering him increased portions of their surpluses. At the same time, they threaten him with sanctions should he defect. But, as nonlegal sanctions imposed by one group increase and the portions of the surpluses offered by competing groups increase, he has less reason to commit himself to any one group. In the competition for members, solidary groups weaken each other's solidarity. ${ }^{69}$

Moreover, tensions arise when factions develop within groups. Union members who seek more benefits clash with members who seek more wages. Religious groups divide over doctrinal and political questions. Trade groups split over economic strategy, families over career and geographical choices. When groups split into factions, each faction develops its own norms and sanctions, its own solidarity.

However, synergies can also arise; solidary groups make alliances. The church preaches the importance of the family; family members urge each other to go to church. In effect, the family and the church save resources by sharing monitoring and sanctioning costs. They can also preserve the surpluses by agreeing, like cartels, to monopolize different collective goods. The family specializes in short-term mutual insurance, household production, and child rearing; the church in insurance against more remote contingencies and in spiritual satisfaction. ${ }^{70}$ Likewise, different churches offer distinctive packages of ritual and doctrine, or they divide up the market geographically.

Similarly, business groups, social clubs, and labor unions often require membership in approved religious organizations, and, of course, are often based on family relationship, social status, membership in the community, and ethnicity. ${ }^{71}$ Ethnic,

See generally James Q. Wilson, Political Organizations 263-67 (Basic Books 1973).

70 Among the Amish, family members join with the rest of the community in shunning a person who breaks the rules. But some religions reject the family, rather than ally with it. Consider the arrangements that frequently prevail in religious cults, where religious (spiritual) and family (sexual and child-rearing) functions are mingled, and members may not interact with their real families. See text accompanying notes 15-18.

${ }_{71}$ See, for example, Max Weber, From Max Weber: Essays in Sociology 307-10 (Oxford 1946) (H.H. Gerth and C. Wright Mills, trans and eds) (business and social groups); Susan Olzak, The Dynamics of Ethnic Competition and Conflict 45 (Stanford 1992) (labor unions). 
community, and cultural relations provide a basis for continuing interaction and observation, a convenient method for distinguishing insiders from outsiders, and, in effect, a bond to guarantee performance. ${ }^{72}$

The phenomenon of multiple membership complicates group regulation. It has several possible effects. First, a group-based rule designed to promote a socially valuable group (say, a union) may weaken another socially valuable group (say, a church) by inducing members of both groups to favor the former over the latter. The union, for example, might begin to offer social functions for which people previously looked to the church.

Second, as suggested earlier, ${ }^{73}$ a group-based rule, rather than increasing the solidarity of a group, may produce (1) increased entry into the group, if the group cannot exclude people effectively; (2) increased competition for membership in the group, if the group can exclude people effectively; and (3) greater competition among groups (including the self-generation of new groups) for the benefits provided by the group-based rules. ${ }^{74}$ For example, subsidies to unions may cause a large number of people to join a union, the use of bribery or similar techniques to obtain membership, and competition by different organizations to represent employees-in all cases, dissipating the benefits of the subsidies and undermining group solidarity. Organizations based on different ethnic groups compete for set-asides and other ethnically based legal advantages. ${ }^{75}$

Third, a category-based rule or an intrusive dispute resolution rule that undermines the solidarity of one group ${ }^{76}$ nonetheless may stimulate the solidarity of another. For example, an antidiscrimination law that weakens the solidarity of a kye to which a Korean entrepreneur belongs might also encourage the formation of interracial business relationships. Overly exacting or arbitrary contract principles might cause traders to restrict business with strangers and fall back on ethnic- or kin-based trading organizations. ${ }^{77}$

${ }^{72}$ See Sumner J. La Croix, Homogeneous Middleman Groups: What Determines the Homogeneity?, 5 J L Econ \& Org 211, 212-17 (1989); Carr and Landa, $12 \mathrm{~J}$ Legal Stud at 150-56 (cited in note 18).

${ }^{73}$ See text accompanying note 31 .

${ }^{74}$ For a discussion of rent-seeking behavior, see Mueller, Public choice II at 229-46 (cited in note 12).

${ }^{75}$ See generally Olzak, Dynamics of Ethnic Competition and Conflict (cited in note 71).

${ }^{76}$ See text accompanying note 32 .

27 Compare Hardin, One for All at 138 (cited in note 12) (arguing that the strong HeinOnline -- 63 U. Chi. L. Rev. 1631996 
Fourth, the state supplies legal sanctions as supplements to groups' nonlegal sanctions in order to help them sustain a kind of monopoly position against competing groups, including factions, that may arise and bid for members. Laws against incest and bigamy, in the case of the family, and laws against membership in multiple unions, spring to mind. This way of reducing the value of independent action and defection ensures that group subsidies do not dissipate among many competing groups. ${ }^{78}$

\section{Summary and Implications}

If the state seeks to modify the law in order to encourage or discourage certain kinds of behavior, it must take account of the dynamics of group behavior in several ways. First, a law designed to modify an actor's behavior by sanctioning or rewarding her may be inferior to a law that subsidizes or penalizes a group to which the actor belongs. Second, a law designed to modify the actor's behavior or wealth may have no effect, or even the opposite of the desired effect, if it incidentally changes the dynamics of groups to which the actor belongs. Third, laws designed to regulate the manner in which groups discipline their members will weaken the groups unless the laws punish only high-value defection from groups with relatively low solidarity. Fourth, laws enacted with the purpose of subsidizing or suppressing certain groups may have perverse results if they fail to recognize the overlap and conflict that prevails among groups. ${ }^{79}$

The effective use of rules in these complicated ways depends on the ability of courts, administrative agencies, and other arms of the state to distinguish between solidary groups and atomistic groups. This is not always a problem. Many solidary groups-for example; "traditional" families, unions, and religious groups-are

norms of family loyalty in southern France and southern Italy resulted from the dominance of hostile external powers for long periods of time; the authorities' neglect fomented distrust between members of the communities who, in the absence of effective police and courts to resolve disputes, fell back on family relations).

${ }^{78}$ This rationale has been proposed for the Catholic Church's celibacy requirement for priests, whose loyalty is therefore not divided between the Church and any children. See Georg Simmel, The Web of Group Affiliations (Reinhard Bendix, trans), in Georg Simmel, Conflict and the Web of Group Affiliations 125, 144 (Free Press 1955). Another example is the practice of successful communes of prohibiting monogamous relationships among members, requiring either free love or celibacy instead. See Kanter, Commitment and Community at 92 (cited in note 17).

${ }_{79}$ The only other systematic attempt (of which I am aware) to propose general, descriptive propositions about the interaction between legal and nonlegal sanctions is Ellickson's. See Ellickson, Order Without Law at 284-86 (cited in note 5). 
easy to identify. It takes only a little more care to detect many less conventional forms of solidarity, such as ongoing relationships between corporate agents, coworkers, neighbors, extended kin, and so on.

However, the line between a solidary and an atomistic group shifts and blurs; indeed, the many existing group-based rules have produced litigation in which courts and agencies must distinguish authentic from spurious religious groups, families, unions, and Indian tribes. ${ }^{80}$ Nevertheless, courts can fall back on a functional test of authenticity when formalities fail-a group is solidary if its members can deter opportunistic behavior with nonlegal sanctions. Assuming that a group performs desirable functions and assuming that it enjoys enough solidarity that it can be expected to remain stable for a suitable period of time (comparable to legally sanctioned arrangements), the law should provide whatever advantages to the informal group it does to comparable legally recognized groups.

\section{CASE Studies}

\section{A. Informal Economic Groups}

"Informal economic groups" or "trade groups" are solidary groups, sometimes but not always based on ethnicity, devoted to obtaining economic or commercial benefits for their members. I use the term broadly to include all sorts of loosely structured associations, such as networks of ongoing business relationships governed by their own norms.

An example comes from the experience of Japanese immigrants and their descendants on the west coast of the United States. When the first immigrants from Japan arrived in the nineteenth century,

[t]heir opportunities for employment were severely restricted. Japanese immigrants were denied citizenship rights and therefore could not lodge complaints against discrimination.

*O On religious groups, see, for example, Africa v Pennsylvania, 662 F2d 1025, 1032 (3d Cir 1981) (rejecting claim that the MOVE organization is a religion). On families, see, for example, Moore $v$ City of East Cleveland, 431 US 494, 506 (1977) (rejecting a local ordinance's definition of a family). On unions, see Robert Gorman, Basic Text on Labor Law, Unions and Collective Bargaining 40-92 (West 1976) (on the certification process of unions). On Indian tribes, see William C. Canby, Jr., American Indian Law in a Nutshell 3-6 (West 2d ed 1988); Bureau of Indian Affairs, Procedures for Establishing that an American Indian Tribe Exists as an Indian Tribe, 25 CFR \$\$ 83.7, 83.8 (1995) (criteria for establishing that an Indian tribe exists). 
New immigrants were forced to take jobs wherever they could get them, and the fact that fellow ethnics offered them an opportunity to establish themselves was bound to produce loyalty. Societal hostility and concentration in small business thus mutually reinforced one another. ${ }^{81}$

These immigrants thus formed solidary associations to protect themselves against discrimination by natives; when the natives reacted by hostilely accusing immigrants of being clannish, the immigrants responded by withdrawing even more. Because these immigrants depended heavily on each other for mutual protection, opportunism was very rare. As a result,

[the] immigrant businesses, dependent upon precapitalisttype bonds of ethnic loyalty, were not only able to survive but could actually thrive within capitalist society. This paradox is resolved by the fact that under certain circumstances, notably in marginal fields of endeavor, noncontractual relations can be less expensive and more efficient than formal contractual ones. ${ }^{82}$

Numerous kin-based networks and ethnicity-based organizations provided contacts, rooms, credit, aid, dispute mediation, and other advantages that ultimately allowed more recent Japanese immigrants and their immediate descendants to dominate certain sectors of the economy-farming, laundries, and grocery stores-and attain an above-average standard of living. ${ }^{83}$ In this way a solidary group, because of discrimination against its members, can obtain transactional economies that offset the economic cost of the discrimination. ${ }^{84}$

Other relations besides ethnicity and other hurdles besides social hostility provide incentives to join solidary associations. All economic actors who have continuing relations develop informal methods to monitor behavior, mediate disputes, and apply nonle12).

${ }^{81}$ Bonacich and Modell, Economic Basis of Ethnic Solidarity at 251-52 (cited in note

82 Id at 253.

33 Id at 37-63, 127-30. As Bonacich and Modell stress, the economic success of an ethnic group, such as the Japanese immigrants, increases the hostility of the larger population, thereby reinforcing the immigrants' mutual dependence and solidarity.

\$4 Other ethnic middleman groups in the United States have included Jews, Koreans and other East Asians, Greeks, and Armenians. Other countries also provide numerous examples, especially expatriate Indians, Pakistanis, and Chinese. See id at 269-71. See also Landa, $10 \mathrm{~J}$ Legal Stud at 351-61 (cited in note 18) (explaining that trading status depends on whether trader is family member, Chinese, or outside middleman). 
gal sanctions. Macaulay's well known study, for example, addresses the relations of manufacturers and their customers. ${ }^{85}$ Other studies analyze the relations-some related to ethnicity, some not-among actors in the garment industry; ${ }^{86}$ consumers and manufacturers of automobiles; ${ }^{87}$ residents of cattle country $;^{88}$ diamond traders ${ }^{89}$ domestic workers; ${ }^{90}$ commercial landlords and tenants; ${ }^{91}$ contractors and subcontractors ${ }^{92}$ and members of trade associations. ${ }^{93}$ Indeed, the relational contract literature focuses on the continuing relations among economic actors on the ground that such relations are far more common than the one-shot deals assumed by traditional contract law analysis and neoclassical economics. ${ }^{94}$

Other less explicitly business-oriented groups provide members with insurance, contacts, training, political power, capital, and other advantages. These groups allow members to achieve economic success despite the hostility of the larger population. Although recent studies have concentrated on voluntary economic and social associations among blacks, Japanese, Koreans, Chinese, Indians, and other minority ethnic groups, ${ }^{95}$ these groups are simply the modern versions of the mutual aid and other voluntary societies created by Polish, Jewish, German, Swedish,

65 See Macaulay, $28 \mathrm{Am}$ Soc Rev at 62-65 (cited in note 2).

$\therefore$ See Sally Falk Moore, Law and Social Change: The Semi-Autonomous Social Field' as an Appropriate Subject of Study, 7 L \& Soc'y Rev 719, 723-29 (1973).

s7 See William C. Whitford, Law and the Consumer Transaction: A Case Study of the Automobile Warranty, 1968 Wis L Rev 1006, 1015-45.

$\Leftrightarrow$ Ellickson, Order Without Law at 185-88 (cited in note 5).

See Bernstein, $21 \mathrm{~J}$ Legal Stud at 151-53 (cited in note 51).

so See Pierrette Hondagneu-Sotelo, Regulating the Unregulated?: Domestic Workers' Social Networks, 41 Soc Probs 50, 61 (1994).

${ }^{91}$ See Spencer MacCallum, Dispute Settlement in an American Supermarket: A Preliminary View, in Paul Bohannan, ed, Law and Warfare: Studies in the Anthropology of Social Conflict 291, 293-99 (Natural History 1967).

$\because$ See, for example, Richard Lewis, Contracts Between Businessmen: Reform of the Law of Firm Offers and an Empirical Study of Tendering Practices in the Building Industry, 9 J L \& Soc'y 153, 168-69 (1982).

See Soia Mentschikoff, Commercial Arbitration, 61 Colum L Rev 846, 849-56 (1961).

${ }^{94}$ See, for example, Ian R. Macneil, Contracts: Adjustments of Long-Term Economic Relations Under Classical, Neoclassical, and Relational Contract Law, $72 \mathrm{Nw}$ U L Rev 854, 896 (1978); Goetz and Scott, $67 \mathrm{Va}$ L Rev at 1092-1111 (cited in note 56).

${ }_{95}$ See, for example, Ivan H. Light, Ethnic Enterprise in America: Business and Welfare Among Chinese, Japanese and Blacks (Berkeley 1972); Thomas Sowell, Ethnic America: A History 292 (Basic Books 1981) (Chinese, Japanese and West Indian rotating credit associations); Trish Hall, The Old-Country Network: Expatriate entrepreneurs help their countrymen navigate New York City's small business maze, Wall St J 51C, 51C-52C (May 20, 1985) (discussing Greek, Korean, Indian, and Pakistani networks). 
Italian, and Irish immigrants (as well as blacks) in the nineteenth century and (sometimes) poorer versions of the social clubs and old boys' networks that continue to facilitate business relations among the mostly white, Protestant, upper-middle class today. $^{96}$

In all of these groups, ${ }^{97}$ solidarity creates relatively effective methods for disciplining members who engage in bad-faith conduct. The ubiquity of these groups supports the commonplace notion that group membership is an important element of economic success. It also raises the intriguing possibility that, because of the prisoner's dilemma, state intervention to promote these groups could have socially beneficial effects.

\section{The rotating credit group.}

We can investigate this point by focusing on Korean "kyes," in part because they provide a particularly clean example of what is usually a messy phenomenon. They also illustrate the importance of informal business associations. Estimates suggest that kyes in Washington, D.C., alone hold more than one hundred million dollars in capital; this at least partly accounts for the disproportionate representation and wealth of KoreanAmericans in the Washington business community. ${ }^{99}$ These

96 See Susan D. Greenbaum, A Comparison of African American and Euro-American Mutual Aid Societies in 19th Century America, $19 \mathrm{~J}$ Ethnic Stud 95, 105-14 (Fall 1991) (comparing African-American associations with those of other immigrant groups); Hechter, Principles of Group Solidarity at 111-13 (cited in note 12) (British and American fraternal societies). See generally Light, Ethnic Enterprise in America (cited in note 95) (blacks, Chinese, Japanese); Sowell, Ethnic America (cited in note 95) (several ethnic groups); Thomas Sowell, ed, Essays and Data on American Ethnic Groups (Urban Institute 1978) (statistical data).

Some studies have attempted to measure the extent to which Americans participate in voluntary associations. It is generally believed that participation is widespread. See, for example, Murray Hausknecht, The Joiners: A Sociological Description of Voluntary Association Membership in the United States 23 (Bedminster 1962).

97 It should be clear, despite my focus on the kye, that solidary relations exist in the "formal" as well as in the "informal" economy. Obviously, the role of solidary relations in the informal economy is especially significant, because actors in that economy cannot usually enforce contracts through legal process. On the significance of the informal economy, see, for example, Saskia Sassen, The Informal Economy: Between New Developments and Old Regulations, 103 Yale L J 2289, 2304 (1994) (arguing that the informal economy is structural, rather than anomalous, in the American economy, and should not be criminalized); United States Department of Labor, The Underground Economy in the United States 20 (1992) (Occasional Paper No 2) (estimates of the size of the United States underground economy in 1980 range from 1.4 percent to 41.6 percent of GNP).

98 For a definition of this term, see note 7.

99 See Joel Garreau, For Koreans 'Keh' Is Key to Success, Wash Post B1 (Nov 3, 1991). In Los Angeles, estimates suggest that kyes financed nearly 30 percent of new businesses 
kyes, however, compose only a fraction of the total number of kyes in the United States, and kyes compose only the tiniest fraction of all the informal trade groups in the United States. ${ }^{100}$

Recall that a rotating credit group typically consists of a small number of people (ten to thirty), who periodically contribute money to a pot. At the beginning of each period, one member takes the pot. Members determine the recipient by lottery or bidding. Failure to make timely payments and other breaches result in nonlegal sanctions such as criticism that, carried along the channels of gossip, injures the defaulter's reputation and may lead to social ostracism. When everyone has taken one pot, the group dissolves.

The rotating credit group enables members to borrow or save in order to purchase indivisible durable goods. ${ }^{101}$ Those who

begun in Koreatown in 1987; 77 percent of the members of the Korean Garment Industry Association participated in a kye; and some kyes pay as much as one hundred thousand dollars per month. David J. Jefferson, Neighborhood Financing: Lending clubs offer social support and quick capital to Asian immigrants, Wall St J R13 (Feb 24, 1989). However, it is difficult to determine the extent to which rotating credit groups and other ethnically based organizations account for the economic success of some ethnic and immigrant groups (which do better than the average native). See, for example, Alejandro Portes and Ruben G. Rumbaut, Immigrant America: A Portrait 58-83 (California 1990) (discussing statistics).

${ }^{100}$ Because academics first noticed that rotating credit groups flourished in less developed economies, early writers thought that they were no more than inefficient banks that would be replaced by real banks as economic development proceeded. See Clifford Geertz, The Rotating Credit Association: A "Middle Rung" in Development, 10 Econ Dev \& Cultural Change 241, 260 (1962). Subsequently, sociologists discovered that advanced economies support numerous rotating credit groups, which prosper despite the competition of banks, credit unions, and other sophisticated financial intermediaries. In the United States, for example, one finds rotating credit groups among Koreans ("kye"), Mexicans ("tanda," "cundida"), Cantonese ("hui"), Japanese ("ko," "tanomoshi," "mujin"), and West Indians ("esusu"). Typically, they exist in large cities, where members live in closely knit groups somewhat segregated from the rest of society. Members are usually first or second generation immigrants, but they often belong to various economic levels and occupations. See Light, Ethnic Enterprise in America at 106, 176 (cited in note 95); Sowell, Ethnic America at 145, 167 (cited in note 95); Carlos G. Vélez-I., Social Diversity, Commercialization, and Organizational Complexity of Urban Mexican/Chicano Rotating Credit Associations: Theoretical and Empirical Issues of Adaptation, $41 \mathrm{Hum}$ Org 107, 119 (1982) (Mexicans and Meso-Americans); Ivan Light, Im Jung Kwuon, and Deng Zhong, Korean Rotating Credit Associations in Los Angeles, 16 Amerasia J 35, 40-47 (No 2 1990) (occupations and locations of kye members); Aubrey W. Bonnett, Institutional Adaptation of West Indian Immigrants to America: An Analysis of Rotating Credit Associations 31-33 (University 1981) (West Indians); Ivan Light and Edna Bonacich, Immigrant Entrepreneurs: Koreans in Los Angeles 1965-1982 247-54 (California 1988) (Koreans).

${ }^{101}$ See Timothy Besley, Stephen Coate, and Glenn Loury, The Economics of Rotating Savings and Credit Associations, 83 Am Econ Rev 792, 807 (1993); Philippe Callier, Informal Finance: The Rotating Savings and Credit Association-An Interpretation, 43 Kyklos 273, 274 (1990). 
take later save; those who take earlier borrow. By agreeing to take an early pot that is smaller than the sum of his total contributions, the early taker pays interest to the late taker (who takes a pot that is larger than the sum of his total contributions). If the pot goes to the winner of a lottery, the earlier takers pay no or low interest for their loans, and the benefit is probabilistic. (Hence the frequency of multiple memberships.) Thus, participation in a rotating credit group either reduces the time necessary to save up to buy an indivisible good or earns interest.

The model developed in this Article helps identify three important attributes of rotating credit groups. First, rotating credit groups deliver a collective good in the form of cheap credit for borrowers and low-risk, high-return investments for lenders. Second, rotating credit groups can deliver this good, despite vast competitive disadvantages with respect to banks, which capture scale economies, because their solidarity avoids the necessity of written contracts, records, courts, lawyers, and professional administrators. ${ }^{102}$ Third, these transactional economies flow from the groups' homogeneity and the hostility of the larger population. Ostracism from a group whose members suffer discrimination from outsiders means isolation, loss of status, loss of security, and economic deprivation. As a result, among West Indian immigrants in New York City, "[s]o rare was default that when queried, most organizers did not know how they would have dealt with such a situation." 103

Assuming that the state has an interest in maximizing social wealth and maintaining public order, how should it respond to rotating credit associations? Rotating credit groups appear socially valuable, because they meet a demand by minorities and other vulnerable people, such as immigrants, for low-cost financial services that banks do not provide. However, this demand might not by itself explain their existence. Rotating credit groups often evade taxes, usury laws, and corporate regulations. ${ }^{104}$ One doubts the importance of usury laws and corporate laws, which are designed to protect uninformed borrowers and investors, when the members share ties of kinship, friendship, and community. ${ }^{105}$ But if tax losses are high, rotating credit groups might

102 See, for example, Light, Ethnic Enterprise in America at 58-61 (cited in note 95); Bonnett, Institutional Adaptation at 59-60 (cited in note 100).

103 Bonnett, Institutional Adaptation at 63-64 (cited in note 100).

${ }_{104}$ Light, Im, and Deng, 16 Amerasia at 41 (cited in note 100).

105 This is not always the case. See, for example, Regina Austin, "The Black Community," Its Lawbreakers, and a Politics of Identification, 65 S Cal L Rev 1769, 1782-83 (1992) 
be socially undesirable. An informed determination requires careful study beyond the scope of this Article. ${ }^{106}$

\section{Group-based and category-based rules.}

De facto exemptions from tax, usury, and corporate laws constitute group-based advantages for rotating credit groups. Clearly, lawmakers did not intend to transfer wealth to rotating credit groups in this way. The interesting question is whether these group-based advantages are socially justifiable on other grounds. As we saw in Part II, efficiency justifies a group-based subsidy when it enables a group to capture a surplus that would otherwise be lost because of the prisoner's dilemma. The extraordinary success of kyes, both in maintaining discipline and generating wealth, suggests that they do produce more wealth for their members than tax and related savings alone could produce. Confirmation of this conjecture, however, requires empirical analysis that is beyond the scope of this Article.

Category-based rules relevant to rotating credit groups include welfare laws, to the extent that the relevant Korean immigrants are poor, and antidiscrimination laws, to the extent that Korean immigrants suffer from discrimination. Recall that category-based rules reduce the cooperation-defection differentials for group members within the category if the benefits they produce are substitutes for the group's surplus. ${ }^{107}$ If welfare laws make Koreans less dependent on the kyes (and their communal ties, generally) for economic security, and if antidiscrimination laws make them less dependent on the kyes for credit, then kyes (and communal ties) become less important to maintain. The cooperation-defection differential may fall to zero, even if a potential

(noting exploitation in black informal economy); Lora Jo Foo, The Vulnerable and the Exploitable Immigrant Workforce and the Need for Strengthening Worker Protective Legislation, 103 Yale L J 2179, 2181-88 (1994) (discussing sweatshops). Austin argues that the black informal economy is on balance beneficial, and proposes, among other things, that the state exempt actors in the black informal economy from certain commercial rules. The proposal illustrates the approach of using group-based rules to foster the solidarity of groups. Austin, $65 \mathrm{~S} \mathrm{Cal} \mathrm{L} \mathrm{Rev} \mathrm{at} 1816$.

${ }_{106}$ Cooter and Landa fear that solidary trading groups may act as cartels. See Cooter and Landa, 4 Intl Rev L \& Econ at 21 (cited in note 18). But cartel-like behavior is only possible in an uncompetitive market; potential entrants and commercial competitors restrain groups (as kyes must compete against banks). Cooter and Landa suggest that a more perfect contract law would solve the problem of cartel-like behavior. Id at 22. Even if feasible, however, this would exacerbate the collective action problem faced by the groups, potentially causing an efficiency loss, rather than a gain.

107 See text accompanying note 32. 
surplus from cooperation (over independent action) remains. If all this is true, antidiscrimination laws and other laws ${ }^{108}$ that transfer wealth to Koreans as a category may reduce the wealth of individual kye members-indeed, possibly by more than any increase in wealth to the category as a whole. ${ }^{109}$

However, this analysis is highly tentative. First, antidiscrimination and other laws may not have these effects on behavior. A crucial assumption is that antidiscrimination laws, as category-based rules, increase the value of defection without also increasing the value of cooperation by an equal or greater amount. Second, any conclusion about efficiency must also take into account the independent, nongroup efficiency effects of welfare and antidiscrimination laws. Still, the argument's logic resembles a concern that has surfaced in recent writings about race relations, namely that civil rights laws and the welfare state discourage cooperative behavior within minority groups. ${ }^{110}$

Richard Epstein makes the related point that in hiring employees, businesses rely on the solidarity of ethnic groups to obtain transactional economies. ${ }^{111}$ Information channels within ethnic networks reduce the cost of advertising for hires, and the desire to maintain a reputation as a good worker within one's

${ }^{108}$ A law worth considering in this context is the Community Reinvestment Act, 12 USC §§ 2901 et seq (1988 \& Supp 1992), which directs federal banking agencies to encourage banks to supply credit to low-income neighborhoods. Some commentators argue that the law, among other things, will encourage banks to avoid doing business in low-income neighborhoods and set up their operations elsewhere. See Jonathan R. Macey and Geoffrey P. Miller, The Community Reinvestment Act: An Economic Analysis, $79 \mathrm{Va}$ L Rev 291, 314-15 (1993). We can add that even if the law caused banks to subsidize their operations in low-income neighborhoods, this effect could injure the intended beneficiaries by giving members of their rotating credit groups incentives to defect to the less efficient banks. The magnitude of this perverse effect will vary: rotating credit groups are less common in poor (non-West Indian) black neighborhoods than in poor Asian and Mexican neighborhoods. See Light, Ethnic Enterprise in America at 23 (cited in note 95).

${ }_{109}$ Apparently, kyes have in recent times become less popular. See Jefferson, Neighborhood Financing, Wall St J at R14 (cited in note 99).

${ }_{110}$ Nineteenth- and early twentieth-century black mutual aid societies illustrate this point. One author attributes their decline to desegregation, which allowed blacks to take advantage of the larger risk pools offered by white-controlled insurance companies. Greenbaum, $19 \mathrm{~J}$ Ethnic Stud at 105 (cited in note 96). Some blacks today lament the loss of the solidarity that existed prior to the civil rights era, when the hostility of whites forced blacks to cooperate with each other in many areas of life. See Peter Applebome, $A$ Sweetness Tempers South's Bitter Past, NY Times 1, 20 (July 31, 1994); Peter Applebome, From Atlanta to Birmingham, Blur of Progress and Stagnation, NY Times A14 (Aug 3, 1994). To lament this loss of solidarity is not, however, to lament the arrival of civil rights; most would find the tradeoff worthwhile.

${ }^{111}$ Richard A. Epstein, Forbidden Grounds: The Case Against Employment Discrimination Laws 69-72 (Harvard 1992). 
community deters opportunism on the job. Laws prohibiting employers from acquiring an ethnically homogeneous workforce prevent employers from exploiting these transactional efficiencies. ${ }^{112}$ This results in increased prices and reduced wages. Epstein does not, but could also, point out that such laws additionally injure the solidary ethnic communities themselves by reducing the value of cooperation with coethnics. But, again, it is difficult to balance these efficiency losses against the gains that the antidiscrimination laws produce in other contexts.

\section{Dispute resolution.}

A recent case in Los Angeles illustrates the argument from Part II.B regarding judicial intervention in dispute resolution. ${ }^{113}$ The case involved a kye, whose thirty-one members each paid in about $\$ 3,334$ per month, and received the right to take a one-time distribution of $\$ 100,000$ on a given month. Some members bought the right to take earlier by agreeing to accept less than $\$ 100,000$, while other members accepted the right to take later in return for the right to make contributions of less than $\$ 3,334$ per month; earlier takers, in effect, borrowed money at interest from later takers.

The case arose in the middle of the cycle, after the organizers of the kye demanded that a member household, Young-Wan and Hyn-Sun Song, supply collateral to secure their future payments. The organizers did not ask any other members to do this. Apparently, the organizers had heard that a relative of the Songs had declared bankruptcy and feared that the Songs were insolvent as well. When the Songs refused to supply the collateral, the organizers told the Songs that they would not receive a distribution. The Songs responded by refusing to make further contributions. One of the organizers, Jung-Hie Park, sued the Songs for damages.

The judge of the Superior Court in Los Angeles ruled that the kye "is in fact a lottery and as such is being operated illegally

"12 Epstein cites a case where the EEOC penalized a small business that hired people exclusively through Hispanic organizations. See id at 70-71. See also EEOC v Consolidated Service Systems, 989 F2d 233 (7th Cir 1993), where the EEOC sued a small Koreanowned janitorial service (annual sales of four hundred thousand dollars) on the ground that its word-of-mouth hiring policies discriminated in favor of Koreans. The EEOC had spent seven years litigating against this business at the time of the appellate decision. Over a period of several years 73 percent of the applicants and 81 percent of the hires were of Korean descent. Id at 235.

113 See text accompanying notes 46-63. 
by the organizers thereof. Further, the operation and organization of the [kye] is also a form of security that is being sold to the individual members without first obtaining a permit from the proper regulatory authorities." ${ }^{114} \mathrm{He}$ accordingly dismissed Park's claim. ${ }^{115}$

To evaluate whether judicial intervention was or was not appropriate in this case, we must focus on the contract law dimensions of the dispute. To this end, imagine the following arguments. The Songs argue that it was never part of the deal that they would have to put up collateral in order to receive their distribution. By withholding the distribution due to the Songs, the organizers breached their side of the bargain, and the Songs justifiably refused to make any additional payments.

The organizers respond that the bankruptcy of the Songs' relative made the Songs an unacceptable risk to the kye. Against background norms that require cooperation among relatives, the Songs' failure to aid their relative and the relative's future inability to aid the Songs indicated financial weakness on the part of the Songs. By requiring the Songs to supply security, the organizers properly exercised their authority, under the terms of the kye, to protect its viability.

But did the organizers have such authority? And, if so, did it include the power to sue the Songs? On this issue, the Songs argue that the organizers' use of the courts violated a group rule against use of judicial process. ${ }^{116}$ If the Songs behaved poorly, they would face nonlegal sanctions; if not, the organizers would face nonlegal sanctions. ${ }^{117}$ Reliance on nonlegal sanctions is surely desirable for the kye, because courts err more often than do solidary groups (as the judge's analogy between the kye and a lottery amply demonstrates). ${ }^{118}$

${ }_{14}$ Park $v$ Song, No BC044756 (Cal Super Ct 1993) (minutes of final status conference) (on file with U Chi L Rev).

${ }^{115}$ Id. See also Kenneth Reich, Court Ruling Deals Blow to the Private Pooling of Money, LA Times B12 (Sept 25, 1993); Dick Goldberg, Judge Finds 'Gae' Is an Illegal Lottery, LA Daily J 1, 20 (Sept 24, 1993); Jake Doherty, An American Wrinkle in Korean Loans, LA Times City Times 3 (Oct 3, 1993).

${ }^{116}$ The norm against resorting to judicial process to resolve disputes is extremely common in solidary groups. See, for example, Macaulay, $28 \mathrm{Am}$ Soc Rev at 61 (cited in note 2) (commercial transactions); Ellickson, Order Without Law at 60-64 (cited in note 5) (cattle ranchers); Mentschikoff, 61 Colum $L$ Rev at 850-52 (cited in note 93) (trade association arbitration).

${ }^{117}$ Such sanctions can be severe. For example, members of future kyes may ban a dishonest organizer.

ns While the judge's ruling that the kye violated securities laws may have been correct, his ruling that the kye was a lottery was erroneous. Lotteries appeal only to risk- 
However, unforeseen contingencies arguably justified this particular suit: the case arose in the aftermath of the Los Angeles riots-a calamitous event for the local Korean community that likely reduced the cooperation-defection differential of members of kyes. The threat of ostracism loses its force when community devastation makes flight an attractive alternative. So, although under ordinary circumstances, nonlegal sanctions would adequately penalize the Songs or the organizers, the extraordinary circumstances of the riots undermined the effectiveness of nonlegal sanctions and justified the organizers' suit. In other words, although the kye contract did not expressly allow organizers to sue defectors following an extraordinary event, the appropriate default rule (the one that the parties would have chosen and that would maximize the ex ante value of the kye) gives this power to the organizers because the available nonlegal sanctions are too weak to deter high-stakes opportunism. We have, thus, in a roundabout way, returned to the argument that courts should be more willing to intervene in cases of high-value defection from less solidary groups than in cases of low-value defection from more solidary groups. ${ }^{119}$

\section{Summary.}

Ethnic, solidary trading groups provide important collective goods to their members, and indeed seem to account for the economic success of some ethnic groups. If this is true, efficiency and

takers because the cost of the ticket exceeds the expected payout. A share in a kye, however, like a savings account with a bank or a loan from a bank, appeals to anyone who seeks to flatten out his consumption over time; the member's contributions, adjusted for interest, equal his expected payout.

119 A recent study of Delaware Chancery opinions observes that they often contain detailed, moralistic descriptions of the good and bad behavior of managers, directors, and lawyers-for example, criticizing a manager for insufficient regard for the shareholders' interests even while holding in the manager's favor. The author argues that the court uses reputational sanctions to deter opportunism, for the small corporate bar can punish wrongdoers by recommending that shareholders refuse to hire them. See Edward B. Rock, The Peculiar Mechanisms of Corporate Law: Delaware Fiduciary Duty Caselaw as Narrative (on file with $\mathrm{U}$ Chi $\mathrm{L}$ Rev). Under this analysis, the court properly intervenes to penalize egregious behavior, and defers to nonlegal sanctions in the face of less egregious behavior. Interestingly, it uses a group-based rule-providing the corporate bar with a free information service-in order to facilitate the spread of information and, thus, the application of nonlegal sanctions against opportunistic actors. See, for example, In re J.P. Stevens \& Co. Shareholders Litigation, 542 A2d 770, 779-80 (Del Chanc 1988) (denying plaintiff's motion for a preliminary injunction while acknowledging its "legitimate questions"); In re Fort Howard Corp Shareholders Litigation, 1988 Del Chanc LEXIS 110, *36 (denying preliminary injunction while noting that "aspects [of the transaction] supply a suspicious mind with fuel to feed its flame"). 
redistributional goals support strengthening such groups, both through group-based subsidies and, except in cases of high-value defection, through judicial deference to group dispute resolution. Does this mean, then, in the end that antidiscrimination laws injure minorities by interfering with their ability to sustain solidary groups? Maybe not, if interference with collective action is dwarfed by the benefits that those laws produce. But, then, if antidiscrimination laws benefit minorities in this way, is it pointless to try to promote the solidarity of their groups? These questions require further study. ${ }^{120}$

A more general point is that if most trading occurs within solidary trading groups, ethnic or otherwise, contract law must take account of this phenomenon. ${ }^{121}$ One possible consequence is that contract law should defer to group mechanisms for dispute resolution, even when these mechanisms are highly informal. Another possible consequence is that the law should interfere with highly valuable transactions between an insider and outsiders when the transactions would violate the rules of the insider's group. ${ }^{122}$ Finally, it may be the case that the law should grant privileges to trading and similar groups. ${ }^{123}$ These issues also require further study.

${ }^{120}$ The question is complicated, because discrimination may be directed against groups, as well as against individuals, and, even when directed mostly against individuals, it may deter cooperation when cooperative behavior is salient. Thus, the greatest amount of cooperation may occur when there is some but not too much discrimination. For example, "[i]n [New York City], relatively infrequent numbers of attacks [on white immigrants] were more beneficial to the survival of immigrant papers than either periods experiencing no attacks or periods with very high numbers of attacks . .." Olzak, $D y$ namics of Ethnic Competition and Conflict at 206-07 (cited in note 71). These data suggest that as the value of independent action declines (because of hostility) and thus the value of the cooperative surplus rises, collective action becomes more likely; but when hostility exceeds a certain threshold, both independent action and collective action are inferior to invisibility.

${ }_{121}$ Mark Granovetter advances the claim that economic interaction is embedded in solidary relations. See Mark Granovetter, Economic Action and Social Structure: The Problem of Embeddedness, 91 Am J Soc 481, 487-91 (1985).

${ }_{122}$ For examples in the context of families, see text accompanying notes 176-78.

${ }_{123}$ The British government supported friendly societies in nineteenth-century England. These were self-regulating, solidary groups that provided health, life, and disability insurance to their members. Group-based advantages for these societies included the right to deposit funds at savings banks at a special rate of interest and certain bankruptcy privileges. The British government supported them because they reduced the government's poor-relief burden. See Hechter, Principles of Group Solidarity at 112-13 \& n 8 (cited in note 12). In the United States, fraternal ethnic associations served similar purposes, but I do not know whether any governments benefitted them with group-based rules. 


\section{B. Labor Law and Employment Law}

The laws governing employment relations usefully display the tension between the use of group-based rules (labor law) to delegate power to groups and the use of category-based rules (employment law) to regulate directly.

Union locals illustrate the analysis of solidary groups in several ways. First, the cooperative surplus consists of the higher wages and superior benefits organized employees receive compared to those obtained by nonunionized workers. The size of this surplus depends on a union's bargaining power. This in turn depends on the substitutability of capital and nonunion labor for union labor, the proportion of labor costs to total costs, the elasticity of consumer demand for the employer's product, and the elasticity of supply of other factors used by the employer for production. ${ }^{124}$ Second, union locals' small size deprives them of scale economies. They lack the bargaining power of the spontaneous contractual alliances between all existing and potential workers that would exist in the absence of transaction costs. Third, union locals' small size allows them to obtain transactional efficiencies. ${ }^{225}$ Because members know and trust each other, they can engage in flexible and disciplined collective action. Fourth, union locals maintain their cohesion through nonlegal sanctions. Indeed, union leaders typically encourage solidarity by binding members together through social activities; consequently, ostracism and other nonlegal sanctions often can be effective. ${ }^{126}$

\section{Group-based and category-based rules.}

The Wagner Act ${ }^{127}$ and other American laws governing labor relations can be understood as a system of rules designed to promote workplace solidarity. ${ }^{128}$ These group-based rules in-

${ }^{124}$ See Barry T. Hirsch and John T. Addison, The Economic Analysis of Unions: New Approaches and Evidence 13 (Allen \& Unwin 1986).

${ }_{125}$ Compare the findings with respect to industrial work groups in Stanley E. Seashore, Group Cohesiveness in the Industrial Work Group 90-95 (Michigan 1954) (high cohesiveness in small groups).

${ }^{126}$ See, for example, Seymour Martin Lipset, Martin A. Trow, and James S. Coleman, Union Democracy: The Internal Politics of the International Typographical Union 69-105 (Free Press 1956); Kornblum, Blue Collar Community at 61-63 (cited in note 55) (describing day-to-day social and union discipline).

${ }_{127}$ National Labor Relations Act, 29 USC $\$ \S 151-69$ (1988).

${ }^{123}$ For an elaboration of this theme and evidence of legislative intent, see Mark Barenberg, The Political Economy of the Wagner Act: Power, Symbol, and Workplace Cooperation, 106 Harv L Rev 1379, 1418-22 (1993). See also Richard Lempert and Joseph Sanders, An Invitation to Law and Social Science: Desert, Disputes, and Distribution 321- 
clude a variety of privileges granted to unions over the years, such as exemption from antitrust laws, mandatory bargaining privileges with the employer over certain subjects, protections for union organization, and rules governing elections. ${ }^{29}$ These rules transfer wealth and power from nonunionized workers, employers, consumers, and other outsiders to unionized or potentially unionized workers. A number of group-based rules, including rules against closed shops, rules allowing employers to hire replacement workers during strikes, and rules prohibiting secondary boycotts, injure unions. However, against the pre-New Deal labor law background, the group-based labor laws clearly manifest an overall state purpose to support unionization.

Do such rules increase the solidarity of unions? Although they increase the value of union membership, they also increase the incentive to free ride. But, since the cooperation-defection differential would remain constant, the labor laws should not affect the incidence of unionization. However, the group-based labor laws must have initially enabled unions to convert some of their increased wealth and power into more effective enforcement mechanisms. ${ }^{130}$

As discussed before, the delegation of power to an organization raises two kinds of problems for the state. Labor law exemplifies these problems. First, the group's interests do not precisely reflect the state's: unions do not merely seek market wages-they seek above-market wages. Moreover, unions sometimes pursue the interests of more powerful factions at the expense of weaker factions. Second, the group helps only its members: unions do not improve the position of nonunionized employees. Nevertheless, group-based rules promote efficiency if they meet three conditions: first, if group-based rules promote union solidarity; second, if unions produce benefits for members that they would not be able to obtain independently; and, third, if the legal promotion of union solidarity increases benefits to union members by more than the cost of any negative externalities resulting from such promotion. ${ }^{131}$

24 (Longman 1986) (arguing that labor laws help unions overcome collective action problem).

129 See Gorman, Basic Text on Labor Law, Unions and Collective Bargaining at 46-49, 624-35 (cited in note 80).

${ }^{130}$ The upsurge in union membership following enactment of the Wagner Act supports this interpretation. See Albert Rees, The Economics of Trade Unions 15 (Chicago 3d ed 1989) (Union membership doubled between 1933 and 1937.).

${ }^{131}$ See Richard B. Freeman and James L. Medoff, What Do Unions Do? 247 (Basic 
Category-based rules (reflected in employment law) transfer wealth from nonworkers (for example, employers, consumers, and the unemployed) to workers. Examples include minimum wage and maximum hours rules, safety regulations, employment discrimination rules, and pension protection rules. These rules narrow the gap between union wage packages and nonunion wage packages by forcing employers to improve the latter without affecting the former. Employee benefits provided by employment law do not in any obvious way complement the benefits provided by unions. Thus, employment laws reduce the cooperation-defection differential and, as a consequence, union solidarity. ${ }^{132}$ One can thus conjecture that the rise of employment law, especially in the 1960 s, accounts in part for the decline of unions. ${ }^{133}$

If employment laws affected employee well-being in exactly the same way as labor laws, this decline would not matter. But the problem with employment laws is that they are insensitive to the varying needs of different workplaces. In some workplaces, an OSHA standard is too strict; in others, it is too lax. ${ }^{134}$ By

\section{Books 1984).}

${ }_{132}$ Thus, one would predict that unions would oppose employment laws. In fact, at various times, unions have opposed employment laws. In the 1910s, "[s]killed workers' unusual bargaining power often enabled them to improve hours and wages and gain workplace reforms that less-skilled workers were unable to gain or defend without legislation. Accordingly, their unions weighed the costs of broad politics (and broad industrial action) more warily than did unions of less-skilled workers." William E. Forbath, Law and the Shaping of the American Labor Movement 55 (Harvard 1991). See also Michael Goldfield, The Decline of Organized Labor in the United States 30 (Chicago 1987) ("U.S. labor unions may be regarded as quite weak in their influence on social legislation."); Rees, Economics of Trade Unions at 9 (cited in note 130) (The AFL, "until the 1930s, opposed efforts to improve the terms of employment through legislation."). The story, however, is complex; often, unions have supported employment laws. Both Forbath and Goldfield attribute unions' lack of support for social legislation to other factors. See Forbath, Law and Shaping at 55, 130-35; Goldfield, Decline of Organized Labor at 27-30. Obviously, an analysis of this phenomenon must consider issues of political economy and historical contingency that exceed the scope of this argument. An employment law that weakens the incentive to unionize over time may nevertheless serve a particular union's short-term interest. At any rate, many American unions, especially the AFL under Gompers, have historically placed more emphasis on obtaining group-based benefits such as bargaining privileges, immigration restrictions, and closed-shop laws than on obtaining social legislation. See Wilson, Political Organizations at 121-29 (cited in note 69).

${ }_{133}$ See George R. Neumann and Ellen R. Rissman, Where Have All the Union Members Gone?, 2 J Labor Econ 175, 179 (1984) (The twenty years after the enactment of the Wagner Act saw a sharp increase in union membership, from 13 percent of the workforce to 35 percent; but between the 1950s and the present, union membership has plummeted.). Because unions have provided mutual insurance, and welfare provides a close substitute, the rise of welfare might also have contributed to the decline of unions. There is some evidence for this hypothesis. See id at 185. For other arguments about the causes of the decline, see Rees, Economics of Trade Unions at 187-90 (cited in note 130).

${ }^{134}$ See Paul C. Weiler, Governing the Workplace: The Future of Labor and EmployHeinOnline -- 63 U. Chi. L. Rev. 1791996 
contrast, unions and employers draw from a fund of information and experience unavailable to government agencies and are therefore likely to agree on more appropriate standards, especially if competitive labor and product markets prevent holdouts on either side. This has led some to argue that employment law alone cannot solve the problems of the workplace, and that the state should therefore both promote strong unions and enforce employment laws. ${ }^{135}$

However, this proposal raises anew the tension between group-based rules and category-based rules. More strongly prounion labor laws enable unions to conspire with employers to evade undesirable employment laws. Stricter employment laws undermine unionization by increasing the value to employees of independent action. Thus, strengthening both labor and employment laws is likely to have little effect on the position of unionized or potentially unionized workers, even assuming uncompetitive markets, or, at least, arbitrary and uneven effects from workplace to workplace. What should the state do?

Assuming, arguendo, that the goals underlying labor and employment law are valid, the state's optimal approach depends on the conditions of a given workplace. In workplaces dominated by solidary and nondiscriminatory unions, the state should enforce labor laws. In atomistic workplaces where conditions make unionization unattractive, the state should enforce employment laws. In marginal workplaces, the state should promote unionization where economic conditions favor unionization and should enforce employment laws where such conditions are absent. ${ }^{136}$ The diversity of workplaces may frustrate legislative implementation of this approach. But judges can use this approach to interpret the law, and agencies can use it when deciding how best to allocate their resources.

\footnotetext{
ment Law 27, 93-94, 152-61 (Harvard 1990).

135 Id at 161; Clyde Summers, Effective Remedies for Employment Rights: Preliminary Guidelines and Proposals, 141 U Pa L Rev 457, 531-32, 537-38 (1992). Compare Charles Fried, Individual and Collective Rights in Work Relations: Reflections on the Current State of Labor Law and Its Prospects, 51 U Chi L Rev 1012, 1040 (1984) (arguing for employment law over labor law), with Cass R. Sunstein, Rights, Minimal Terms, and Solidarity: A Comment, 51 U Chi L Rev 1041, 1059 (1984) (pointing out deficiencies of employment law and suggesting the importance of labor law for promoting solidarity).

${ }^{136}$ To be sure, an employer who can easily substitute capital for labor would just as likely fire people under a regime of employment law as under a regime of labor law. But presumably the remaining employees would obtain superior benefits, and this tradeoff is apparently consistent with the policy of employment laws.
} 


\section{Dispute resolution.}

Unions' nonlegal sanctions range from social pressure, to fines, to intimidation and assault. ${ }^{137}$ The Wagner Act of $1935,{ }^{138}$ which regulated the employer's treatment of its employees more heavily than the union's treatment of its members, tolerated-and even encouraged-nonviolent sanctions. But perceived abuses by unions led to greater regulation under the TaftHartley Act of 1947. ${ }^{139}$ This law enabled workers to bring unfair labor practice charges against unions. The continuing trend in favor of worker rights has led to rules preventing unions from (1) restricting members' attempts to file unfair labor practice charges against them; (2) encouraging members to violate collective bargaining agreements; and (3) restricting members' participation in union affairs. ${ }^{140}$

If the state seeks to strengthen unions, it should not shield workers from union discipline except in cases of high-value opportunism by leaders in relatively low-solidarity unions. The prevailing intrusive approach suggests suspicion about the integrity of unions. ${ }^{141}$ But even assuming a policy of promoting union solidarity, the appropriate level of intervention should vary. Because different unions enjoy different levels of solidarity, what would count as high-stakes opportunism in one union may count as low-stakes opportunism in another. ${ }^{142}$ As in the case of group-based and category-based rules, agencies and courts must be sensitive to levels of solidarity when intervening in disputes.

\section{Religious Groups ${ }^{143}$}

Religious congregations produce a variety of collective goods for their members, including spiritual satisfaction, a sense of

${ }^{157}$ See, for example, Lipset, Trow, and Coleman, Union Democracy at 164 (cited in note 126); Rees, Economics of Trade Unions at 25 (cited in note 130) (social pressure).

13329 USC $\S 151$.

13929 USC $\$ \S 141$ et seq (1988). See also Gorman, Basic Text on Labor Law, Unions and Collective Bargaining at 5-6 (cited in note 80).

${ }^{140}$ See Gorman, Basic Text on Labor Law, Unions and Collective Bargaining at 680-89 (cited in note 80).

${ }^{141}$ Compare, for example, the freer reign given to families. See Part III.D.

142 For example, a refusal by a member to attend a meeting or rally might be deterrable by a strongly solidary union, but not by a weakly solidary union.

${ }^{143}$ I discuss religious groups more fully in Eric A. Posner, The Legal Regulation of Religious Groups (on file with U Chi L Rev). Some of the arguments in that article and in this Part originate with Adam Smith. See Adam Smith, 2 An Inquiry into the Nature and Causes of the Wealth of Nations 788-814 (Clarendon 1976). See also Laurence $R$. Iannaccone, Religious Markets and the Economics of Religion, 39 Soc Compass 123 (1992). 
community, education, and moral discipline. They produce these goods in part by instilling in members discipline that is unavailable elsewhere in society. Like trade groups and union locals, religious groups choose a size that allows them sufficient resources but does not sacrifice monitoring economies. By limiting the congregation to a small number of people, the religious leadership ensures that everyone knows everyone else and can effectively impose sanctions on deviants. Thus, religious groups maintain discipline by imposing nonlegal sanctions, either hierarchically (from the leadership) or horizontally (among the members). ${ }^{144}$

\section{Group-based and category-based rules.}

Suppose the state seeks to encourage socially valuable religious groups and discourage socially costly religious groups. Current group-based advantages include tax exemptions for religious organizations and for charitable contributions to religious organizations, and subsidies to social agencies operated by religious groups. ${ }^{145}$ History also supplies abundant examples of groupbased disadvantages, including the denial of civil rights and business opportunities, not to mention taxation, imprisonment, and execution.

Tax exemptions may increase the solidarity of religious groups. If so, religious groups would produce a supply of collective goods closer to the optimal level. Although some of these collective goods-for example, spiritual satisfaction-might not interest the state, other collective goods might have significant positive externalities-such as the reduction of poverty among members and nonmembers associated with mutual aid and chari

144 Among the Amish, for example, rule breakers must endure a public confession or, if they refuse, face excommunication and shunning. If a person is shunned, no one will eat, speak, do business with, or otherwise interact with that person. "For the unrepentant, social avoidance becomes a life-time quarantine." Donald B. Kraybill, Negotiating with Caesar, in Donald B. Kraybill, ed, The Amish and the State 3, 11 (Johns Hopkins 1993). See also Robert L. Kidder, The Role of Outsiders, in Donald B. Kraybill, ed, The Amish and the State 213, 230-31 (Johns Hopkins 1993) (describing orthodox Amish practice of ostracizing members who mingle with outsiders). Notice that the leadership declares the sanction, but its implementation requires the participation of all members.

${ }^{145}$ See Walz $v$ Tax Commissioner, 397 US 664 (1970) (property tax exemption); Hernandez $v$ Commissioner of Internal Revenue, 490 US 680 (1988) (income tax deduction for charitable contribution); Bowen $v$ Kendrick, 487 US 589 (1988) (grants for counseling centers run by religious groups). 
ty, ${ }^{146}$ and the reduction of deviant behavior. ${ }^{147}$ But the usual qualifications apply. Some religious groups treat their members in a way that is inconsistent with the state's interests (for example, child abuse) and engage in antisocial activity (such as draft resistance). Even the more mainstream religious groups might undermine the state's goals, for example, by redistributing the subsidy to their members, rather than using it to improve their solidarity. Finally, subsidization of religious groups does not benefit nonmembers (except indirectly as beneficiaries of religious charity).

These problems may justify the state's use of category-based rules to provide substitutes for religiously produced collective goods, such as welfare law for poverty and the criminal law for deviant behavior. However, the model predicts that, as the state imposes more rigorous rules governing moral conduct, religious institutions will weaken: as laws become more severe and certain, people can depend on the law to deter them and their children from engaging in deviant behavior. This argument, though, assumes that people join religions for discipline, when in fact people join religions for a multiplicity of reasons. Moreover, criminal laws are crude instruments compared to the social pressures that a solidary church can exert. As such, they are poor substitutes for these pressures.

It also follows that the welfare system undermines religious organizations. Although, to my knowledge, no empirical study supports this proposition, the intuition is powerful enough to have motivated the Amish to seek and obtain a limited exemption from the Social Security system.

Their current social welfare structure of mutual reliance among members greatly strengthens Amish communal solidarity. If individuals began receiving income from outside the community through Social Security or other social welfare programs, the Amish fear that community ties would be undermined and the cohesiveness of their culture threatened. ${ }^{148}$

${ }^{145}$ See Jeff E. Biddle, Religious Organizations, in Charles E. Clotfelter, ed, Who Benefits from the Nonprofit Sector? 92, 95-104 (Chicago 1992).

${ }^{147}$ The empirical impact of religious groups on deviance is controversial. See L.E. Ross, Religion and Deviance: Exploring the Impact of Social Control Elements, 14 Soc Spectrum 65 (1994); John K Cochran, Peter B. Wood, and Bruce J. Arneklev, Is the Religiosity-Delinquency Relationship Spurious? A Test of Arousal and Social Control Theories, 31 J Res Crim \& Delinq 92, 113-14 (1994).

${ }^{149}$ Peter J. Ferrara, Social Security and Taxes, in Donald B. Kraybill, ed, The Amish 
The Social Security exemption for religious organizations that "make provisions for their dependent members"149 is a groupbased rule that delegates power to religious groups. The state, in effect, free rides on their disciplinary mechanisms and their internal provision of welfare. In the case of the Amish-who have few illegitimate teenage pregnancies, divorces, abusers of drugs or alcohol, and cases of unemployment-poverty is rare, and group delegation effectively serves the state's interests. ${ }^{150}$

The religion clauses of the United States Constitution, however, restrict the ability of the state to manipulate religious groups in order to promote social goals. ${ }^{151}$ Does the theory of group solidarity shed light on the proper scope of these clauses? To see that it does, suppose a religious group becomes powerful in a community, and the local government provides benefits to the group in exchange for support from that group's leadership. The resulting increase in the size of the group's surplus stimulates an increase in membership. Meanwhile, the religious leadership feels pressure to alter its message and practices to conform to the state's needs, for example, by exhorting church members to vote for $\mathrm{X}$. Although this message would presumably increase the number of people who vote for $\mathrm{X}$, it would also alienate some members of the congregation, weakening its solidarity.

In an effort to strengthen such a useful ally, the state could increase the surplus still further by, for example, conditioning state employment on group membership. More people would rush to join the group, swelling its ranks. But the true believers (who, by hypothesis, desire the discipline of religion) leave and join weaker, rival religious organizations. Eventually, the original church becomes an agency of the state; state money and police maintain discipline. Legal sanctions replace nonlegal sanctions. The state has, by now, lost the ability to free ride on the religious group's internal discipline.

This story suggests, then, not only why governments are tempted to favor some religions over others, but also why the long-term interest of the state resides in free exercise and disestablishment. ${ }^{152}$

and the State 125, 130 (Johns Hopkins 1993). Of course, they also oppose participation for purely religious reasons.

${ }_{149} 26$ USC $\$ 1402(\mathrm{~g})(1)(\mathrm{D})$ (1988).

150 See generally Ferrera, Social Security and Taxes at 125-43 (cited in note 148). Interestingly, an Amish person loses her social security exemption if she is excommunicated. See Borntrager v Commissioner, 58 Tax Ct Mem Dec (CCH) 1242, 1243 (1990).

${ }^{151}$ US Const, Amend I.

152 For a more detailed discussion, with qualifications, see Posner, Legal Regulation of 


\section{Dispute resolution.}

The Free Exercise Clause and common law principles of free association not only prevent people from suing a religious group for expelling them, but also religious groups from suing people for exiting. ${ }^{153}$ However, there are a few cases involving suits by people ostracized from Amish and Mennonite sects against their former coreligionists; in some of these cases, the courts have awarded damages. For example, in 1946 Andrew Yoder sued four Amish officials for excommunicating him after he switched to another Amish sect that allowed members to drive automobiles. A court awarded five thousand dollars in damages. ${ }^{154}$ In two earlier cases (in 1878 and 1919) excommunicated plaintiffs also won relief. ${ }^{155}$

The jury in the Yoder case evidently believed that the practice of shunning was offensive and that Yoder deserved damages for emotional harm. If so, the award interfered with the group's dispute resolution mechanisms, and, whether intended by the jury or not, weakened the solidarity of the sect.

By contrast, in another incident, a shunned member of an Amish sect sought revenge by trying to sell his land to an entrepreneur who planned to develop it for commercial purposes. ${ }^{156}$ The Amish feared that commercial development would disturb their way of life and corrupt their children, but lacked any sanction beyond ostracism to prevent the sale. However, non-Amish neighbors and other outsiders lobbied local authorities to enact a zoning ordinance that would prohibit the sale. ${ }^{157}$ Viewed pro-

Religious Groups (cited in note 143).

$1 \times 3$ With respect to common law principles, see Watson $v$ Jones, 80 US (13 Wall) 679, 730-34 (1871). With respect to the Free Exercise Clause, courts refuse to interfere with dismissals of religious officials and sometimes even with dismissals of teachers employed by religious schools. See EEOC Policy Guidance on Pay Discrimination by Religious Organizations, 41 Daily Labor Rep (BNA) D-1 (Mar 1, 1990); Miller v Catholic Diocese, 224 Mont 113, 728 P2d 794, 797 (1986) (Free Exercise Clause barred fired teacher's tort claim against religious school.); Dayton Christian Schools, Inc. v Ohio Civil Rights Commission, 766 F2d 932, 961 (6th Cir 1985), rev'd on other grounds and vacated, 477 US 619 (1986) (Free Exercise Clause barred fired teacher's sex discrimination claim against religious school.). See generally Serbian Eastern Orthodox Diocese v Milivojevich, 426 US 696, 708-20 (1976) (First Amendment limits the reach of civil courts.).

${ }_{154}$ See John Howard Yoder, Caesar and the Meidung, 23 Mennonite Q Rev 76, 77 (1949).

w5 See id at 78. See also Paul $v$ Watchtower Bible and Tract Society of New York, Inc., 819 F2d 875, 883 (9th Cir 1987) (ostracism by Jehovah's Witnesses). For other cases and further discussion, see Posner, Legal Regulation of Religious Groups (cited in note 143).

15 See Kidder, Role of Outsiders at 231-32 (cited in note 144).

157 The outcome of the dispute is unclear. See id. 
spectively, the neighbors thus attempted to deter high-value defections, and their willingness to do so may have promoted the solidarity of the sect.

Schism-a dispute involving a high-value issue, such as control of church property-provides a useful contrast to lowstakes ostracism cases. Specifically, because schism involves a high-value dispute between members of a low-solidarity group, state intervention is more justified. ${ }^{158}$

\section{Families}

Families illustrate the analysis of solidary groups in familiar ways. ${ }^{159}$ First, the cooperative surplus consists of (1) mutual insurance (one spouse supports the other during periods of unemployment $t^{160}$, and (2) child production and socialization (children raised by two spouses are less likely to engage in deviant behavior than children raised by a single parent ${ }^{161}$ ). To the extent that family members perform all household functions, they lose the scale economies of the differentiated labor market, but the family's small size allows it to obtain transactional economies. Intimate knowledge of the personalities and the daily behavior of each member facilitates monitoring and sanctioning. Finally, family members deter opportunism by disciplining each other in various ways, including criticism or, in the extreme, exit or expulsion from the household.

\section{Group-based and category-based rules.}

Tax subsidies to families, zoning ordinances that reserve pleasant areas for families or family-size houses, antidiscrimination rules that prevent landlords from discriminating against children, public schooling, and other group-based laws benefit people who form families. Rules that disadvantage illegitimate children and that deny testamentary and alimony

158 See Posner, Legal Regulation of Religious Groups (cited in note 143).

159 I concentrate on nuclear families; however, "personal networks," consisting both of kin and non-kin, are also solidary groups that perform similar functions and encounter similar problems. See generally Claude S. Fischer, To Dwell Among Friends: Personal Networks in Town and City 5 (Chicago 1982).

${ }_{160}$ Gary S. Becker, A Treatise on the Family 357 (Harvard enlarged ed 1991).

161 See, for example, Maureen M. Black and Izabel B. Ricardo, Drug Use, Drug Trafficking, and Weapon Carrying Among Low-Income, African-American, Early Adolescent Boys, 93 Pediatrics 1065, 1067-69 (1994) (suggesting that family pressures discourage some deviant behavior by children); Coleman, Foundations of Social Theory at 595-97 (cited in note 12). 
benefits to unwed cohabitants promote the formation of families by making substitutes less attractive. Arguably, laws against prostitution, pornography, adultery, and fornication privilege sexual relations that occur between spouses. In addition, some group-based laws injure families-most notoriously, the marriage penalty in the tax code. ${ }^{162}$ On the whole, however, group-based rules in this area appear to increase the cooperation-defection differential: tax and property benefits increase the value of family membership, while divorce laws deprive defectors of the ability to obtain any of these benefits.

Suppose families discourage deviant behavior by children, poverty among adults, and other forms of disorder more effectively than the state. If group-based rules increase the cooperationdefection differential at minimal administrative cost, then they promote efficiency (and, possibly, redistributive goals). By delegating power to families, the state free rides on their more effective disciplinary powers.

However, group-based rules raise the familiar problem that not all benefitted groups behave in the manner desired by the state. Some families do not provide the spouses with insurance and the children with a proper home life. Instead, one spouse tyrannizes the other, or either spouse tolerates deviant behavior from the child. ${ }^{163} \mathrm{~A}$ weak state might tolerate abuses in some families because it depends heavily on families to maintain order; a stronger state could use category-based rules and judicial interference in dispute resolution to address such abuses.

The relevant category-based rules, corresponding to the mutual insurance and child production justifications for supporting families, are (1) laws that insure adults and (2) laws that provide benefits for children. Welfare laws, such as general assistance, AFDC, and foster care programs, spring to mind. By providing insurance for adults and benefits for their children, these laws provide a substitute for similar collective goods provided by families.

Welfare laws may undermine the family by making nonfamily life a relatively attractive alternative. Some evidence, for example, suggests that AFDC has contributed to increased divorce rates by allowing spouses to rely on state assistance rather than on each other in time of need. ${ }^{164}$ Laws prohibiting dis-

${ }^{163}$ See Black and Ricardo, 93 Pediatrics at 1069 (cited in note 161) (Some adolescents report that parents tolerate their drug activity.).

${ }_{16}$ See, for example, Oliver C. Moles, Marital Dissolution and Public Assistance Pay- 
crimination on the basis of illegitimacy would have a similar effect. Despair about the effectiveness of welfare laws and the conviction that families can provide these benefits more effectively doubtless underlie current calls for welfare reform. But it is an open question whether a reduction in welfare would promote the solidarity of families and encourage production of the attendant benefits to their members. Moreover, it is equally uncertain whether such benefits, if they occurred, would justify the hardships imposed on people who do not belong to solidary and effective families.

\section{Dispute resolution.}

If, for example, the state has an interest in promoting the solidarity of all families, an appropriate rule for deterring defection is not a no-divorce rule, as one might expect. Like the kye dispute, one must distinguish between high-value and low-value defection. The party that wishes to escape the family may be the opportunist, but equally he or she may not; in the latter case, a remedy would be justified.

For example, a man may be tempted to marry a woman who will support him through graduate school, and then abandon her when he can support himself. Supposing that a court could reliably untangle the equities, a regime that allowed such husbands to escape sanctions would produce weaker families than a regime that supplied legal sanctions for such behavior-such as a nodivorce or alimony law-because the "family" (the wife and children, if any) would be unable to deter the husband's behavior using nonlegal sanctions. Therefore, a no-divorce law or an alimony law would deter opportunistic marriages and promote more solidary, though fewer, marriages. ${ }^{165}$

ments: Variations among American States, $32 \mathrm{~J}$ Soc Issues 87, 97-99 (1976) (finding correlation between states with higher welfare benefits and states with higher ratios of separated to married mothers but unsure of direction of causation).

165 Since unmarried cohabitants may have solidarity, the analysis suggests that courts should intervene to the same extent as they do with more easily recognizable families, provided that both the indicia of solidarity and equivalent positive externalities are present. Compare Marvin v Marvin, 18 Cal 3d 660, 134 Cal Rptr 815, 832 (1976) (Nonmarital partner may create contract and property rights.), with Hewitt $v$ Hewitt, 77 IIl 2d 49, 394 NE2d 1204, 1211 (1979) (Nonmarital partnership lacks legal status.). See also Moore $v$ City of East Cleveland, 431 US 494, 506 (1977) (striking down single-family zoning ordinance that defined family in a highly limited way). See generally Mary Ann Glendon, The Transformation of Family Law: State, Law, and Family in the United States and Western Europe 277-84 (Chicago 1989). 
The problem with a no-divorce law is that it still enables the husband to behave opportunistically within the marriage, for example, by treating the wife cruelly. By contrast, a no-fault divorce law that allowed the wife to sue for divorce and receive alimony would discourage such conduct and, again, promote the solidarity of marriages. ${ }^{166}$ However, a no-fault divorce law with no alimony requirements would weaken the solidarity of families by allowing opportunists to escape their obligations. The appropriate solution, then, may be no-fault divorce with fault-based alimony, where "fault" is defined as opportunistic behavior that a family's ordinary nonlegal sanctions cannot deter. ${ }^{167}$

By contrast, the law should not resolve relatively minor household disputes. These disputes are unlikely to involve highstakes opportunism; one expects, moreover, that the spouses and children can divide responsibilities among themselves more effectively than would the state. Indeed, internal readjustments would counteract any attempts by the state to regulate the division of responsibilities in solidary families. This may explain the historic restrictions on tort and contract suits between family members. ${ }^{168}$

If the only purpose of family law were to promote the solidarity of the family, a reluctance to intervene except in extraordinary circumstances would make sense. As in the case of economic and religious groups, the courts should decline to resolve disputes whenever the group's nonlegal sanctions adequately deter opportunistic behavior.

Iis I have assumed in the examples that the husband has the wealth and power, although, of course, that is not always true.

167 Compare Margaret F. Brinig and Steven M. Crafton, Marriage and Opportunism, $23 \mathrm{~J}$ Legal Stud 869, 892-93 (1994) (supporting fault-based alimony).

${ }^{163}$ These restrictions are weaker than they used to be. At common law, spouses could not sue each other in tort or for breach of contract. W. Page Keeton, et al, Prosser and Keeton on the Law of Torts 901-02 (West 5th ed 1984); Joseph Warren, Husband's Right to Wife's Services, 38 Harv L Rev 421, 421-22 (1925). Today, many states still forbid negligence suits between spouses, and others allow them but scrutinize them more carefully than negligence suits between strangers. See Keeton, et al, Law of Torts at 903-04. In the contract area, spouses cannot sue each other for breach of contract as easily as strangers can sue each other. For example, courts often forbid spouses from suing each other over contracts relating to labor in the home. See, for example, Borelli $v$ Brusseau, $12 \mathrm{Cal}$ App 4th 647, 16 Cal Rptr 2d 16, 20 (1993) (refusing to enforce a promise by one spouse to pay the other spouse for care during an illness). See also Lenore J. Weitzman, The Marriage Contract: Spouses, Lovers, and the Law 338-47 (Free Press 1981) (describing traditional law); Judith T. Younger, Perspectives on Antenuptial Agreements, 40 Rutgers L Rev 1059, 1071-72 (1988) (Courts generally refuse to enforce provisions in antenuptial agreements relating to the structure of the marriage, domestic and sexual obligations within the marriage, child rearing, and so on.). 
However, if families frequently engage in or tolerate deviant behavior, the state should intervene in disputes and apply category-based rules (or even group-based disadvantages). These rules, by increasing the cost of nonlegal sanctioning in the family and by increasing the value of independent action, reduce the solidarity of families. The trend in favor of such laws-including no-fault divorce laws, child abuse laws, and spousal abuse laws-along with the trend toward category-based advantages mentioned above, may help account for the increase in divorce, illegitimacy, and other family-related problems over the last several decades. ${ }^{169}$

In a recent article, Carol Rose has argued that women's propensity to cooperate - either real or perceived-explains the wealth inequality between men and women. In marriages, the workplace, and elsewhere, men systematically obtain larger portions of bargaining surpluses, and over time they acquire a larger share of social wealth. ${ }^{170}$

Rose's discussion is useful in two ways. First, by emphasizing the abusive relations that occur within the family, it reminds us of the coercive side of solidarity. A state's commitment to the family, like a commitment to any other solidary group, requires toleration of a higher level of abusive behavior between group members than that tolerated between strangers. Judicial intervention might reduce this abuse; but it would also reduce family solidarity (in the "good" families as well as the "bad" ones) and, as a result, social wealth. The same can be said for trade groups, unions, and religious groups. Indeed, the same holds true for the very groups that Rose proposes women form in order to assist each other. That is the irony: these groups, to the extent they are truly solidary, provide the same opportunities for abuse as families. ${ }^{171}$

Second, Rose's proposal that women form solidary groups notes, but understates, the difficulties of group formation. Her use of immigrant groups as an analogy is illustrative. ${ }^{172}$ Immigrants have been successful at forming solidary institutions, like

169 See Becker, Treatise on the Family at 356-61 (cited in note 160). See also Mary Ann Glendon, Marriage and the State: The Withering Away of Marriage, 62 Va L Rev 663, 711-15 (1976); Hechter, Principles of Group Solidarity at 57-58 (cited in note 12).

${ }_{170}$ See Carol M. Rose, Women and Property: Gaining and Losing Ground, $78 \mathrm{Va} L \mathrm{Rev}$ 421,441 (1992).

171 Id at 457. Rose acknowledges the importance of discipline and thus the possibility of abuse.

172 Id at 455 . 
the kye, not only because they are victims of discrimination but also because they live close together, know each other well, interact frequently, share cultural backgrounds, jointly suffer (in some cases) from ignorance of the dominant language, and so on. Even if women have a "taste for cooperation," there are few comparable situational factors that would naturally lead them to form solidary groups. ${ }^{173}$ Indeed, because the members of successful allmale immigrant institutions presumably lack this taste, other factors, unrelated to sex, must account for their solidarity.

\section{A note on families and contract law.}

If the courts seek to promote family solidarity, they should not punish low-stakes opportunism, including low-value, intrafamily torts or breaches of contracts. Because historically (and, to a lesser extent, currently) courts have considered the family protected by public policy, their doctrines should, and, to some extent do, reflect this policy.

I have already mentioned the laws on interspousal immunity. ${ }^{174}$ Consider also the courts' reluctance to enforce gratuitous promises. If one assumes that people give gifts in order to make the recipients better off, then legal enforcement would improve both parties' positions without harming anyone. If courts enforce a gratuitous promise, the donee can more easily plan around it and the donor can confer additional value - in the form of certainty-on the donee. Thus, judicial reluctance to enforce gratuitous promises has puzzled commentators. ${ }^{175}$

If we assume that unenforced gratuitous promises are generally made within solidary groups (such as families), as opposed to between strangers, then the theory advanced here may offer a solution to this problem. As I have discussed, the family's nonlegal sanctions deter opportunism more effectively than do legal sanctions. If judges enforced intrafamily promises, they would overlay the nonlegal sanctions with legal sanctions, and substitute their relative ignorance for the family's informational advantages, thus preventing optimal gift-giving behavior. ${ }^{176}$ Because

173 Id at 426.

${ }^{134}$ See note 168 and accompanying text.

135 See Andrew Kull, Reconsidering Gratuitous Promises, 21 J Legal Stud 39, 64-65 (1992) (supporting enforcement); Steven Shavell, An Economic Analysis of Altruism and Deferred Gifts, $20 \mathrm{~J}$ Legal Stud 401, 419 (1991) (same). But see Melvin Aron Eisenberg, Donative Promises, 47 U Chi L Rev 1, 32 (1979) (supporting enforcement where promise is formal and reliance has occurred).

${ }^{176}$ See Charles J. Goetz and Robert E. Scott, Enforcing Promises: An Examination of 
the family can more easily evaluate excuses for not honoring a promised gift (such as financial misfortune) than can a judge, and can also impose sanctions more effectively, routine judicial intervention would increase the value of defection while reducing the value of the collective good.

However, judicial intervention under unusual conditions may be justified. For example, courts intervene when the donor dies unexpectedly and the executor refuses to fulfill a gratuitous promise. ${ }^{177}$ Because death is a contingency that removes the force of nonlegal sanctions, it justifies legal intervention. Courts are also more willing to intervene and enforce donative promises that do not occur within a solidary group, such as donative promises to charities and other strangers, than they are those between relatives. ${ }^{178}$

Like the reluctance to enforce gratuitous promises, courts' reluctance to enforce contracts with minors has encountered a great deal of criticism. Writers have criticized the capacity doctrine, under which minors often are not bound to contracts they enter, on the grounds that (1) it is arbitrary because it prevents courts from evaluating on a case-by-case basis, as they do with adults, whether a particular minor is incompetent; (2) it unfairly injures people who reasonably assume that a contracting partner is an adult; and (3) it injures minors by discouraging people from contracting with them. Conventional defenses appeal to the ruleversus-standard catechism as a response to (1), and express the usual regrets with respect to (2) and (3). ${ }^{179}$ Most modern commentators, however, agree that the doctrine is indefensible. ${ }^{180}$

The model reveals the rationality of the capacity doctrine. The doctrine reduces the payoff to minors from defection (by

the Basis of Contract, 89 Yale L J 1261, 1322 (1980) (Nonlegal sanctions may justify nonenforcement of gratuitous promises.).

177 See, for example, Hamer v Sidway, 124 NY 538, 27 NE 256, 259 (1891) (uncle's gratuitous promise enforced after his death); Ricketts $v$ Scothorn, 57 Neb 51, 77 NW 365, 367 (1898) (grandfather's gratuitous promise enforced after his death). Writers often interpret these and similar cases to mean that an element of reliance is necessary to render a gratuitous promise enforceable. However, on my analysis, reliance is unimportant. Compare Shavell, $20 \mathrm{~J}$ Legal Stud at $419-20$ (cited in note 175) (opposing the reliance requirement).

${ }^{178}$ See, for example, Allegheny College v National Chautauqua County Bank, 246 NY 369, $159 \mathrm{NE} \mathrm{173,} 177$ (1927) (Cardozo) (enforcing gratuitous promise to charity).

179 See Robert G. Edge, Voidability of Minors' Contracts: A Feudal Doctrine in a Modern Economy, $1 \mathrm{Ga} L \mathrm{~L}$ Rev 205, 222-27 (1967) (describing and criticizing the conventional defenses of the infancy doctrine).

${ }^{180}$ See, for example, E. Allan Farnsworth, Farnsworth on Contracts $\S 4.3$ at 378 (Little, Brown 1990). 
limiting their ability to enter into contractual relations outside the family) without also reducing the value of remaining in the family. The increase in the cooperation-defection differential discourages minors from leaving the family, and thus produces more solidary families. ${ }^{181}$ On this theory, the fact that the capacity doctrine discourages people from contracting with minors is a virtue, not a cause of regret.

Concerns about maintaining the family and similar solidary groups doubtless account for other divergences in contract law from the principle that courts should enforce all voluntary contracts; however, these concerns lie beyond the scope of this Article. ${ }^{182}$

\section{CONCLUSTON}

The legal analyst ignores norms and nonlegal sanctions at his peril. A focus on the interaction between law and nonlegal sanctions shows how nonlegal sanctions in particular, and group action in general, subvert and transform legal regulation of behavior. But if the existence of solidary groups complicates the state's attempts to regulate behavior, it also presents the state with opportunities. Solidary groups supply collective goods that people otherwise demand from the state. Through policies of selective support, the state can effect increases in the supply of these goods more cheaply than it could supply them itself through direct or category-based regulation. In fact, everywhere one looks in the law, one finds rules concerning the promotion, exploitation, and suppression of groups, rather than the exclusive concern with individual action predicted by conventional liberaleconomic analysis. ${ }^{183}$

${ }^{1} \$ 1$ Attempts in the case law to rationalize the capacity doctrine along conventional lines are unconvincing. See, for example, Halbman $v$ Lemke, 99 Wis 2d 241, 298 NW2d 562,564 (1980) ("Although the origins of the doctrine are somewhat obscure, it is generally recognized that its purpose is the protection of minors from foolishly squandering their wealth through improvident contracts with crafty adults who would take advantage of them in the marketplace."). In support of my theory, see Webster Street Partnership, Ltd. $v$ Sheridan, $220 \mathrm{Neb} 9,368 \mathrm{NW} 2 \mathrm{~d} 439,443$ (1985) ("If, indeed, landlords may not contract with minors, except at their peril, they may refuse to do so. In that event, minors who voluntarily leave home but who are free to return will be compelled to return to their parents' home-a result which is desirable.").

${ }_{1 \times 2}$ It is interesting to note that the equitable predecessors to the unconscionability doctrine and similar contract and consumer protection rules emerged from a policy pursued by seventeenth- and eighteenth-century equity courts of protecting landed families from dissipation of their wealth by expectant heirs. See the discussion in Posner, $24 \mathrm{~J}$ Legal Stud at 314-16 (cited in note 44).

1:3 Other applications include American Indian law, see Canby, American Indian Law HeinOnline -- 63 U. Chi. L. Rev. 1931996 
A thorough understanding of this behavior requires one to shake off what I called the "insulation theory" of nonlegal sanctions. This theory implies that legal analysts can ignore nonlegal sanctions because they have uniform and predictable effects. If an analysis, for example, suggests that an optimal law is $\mathrm{X}$, and it is pointed out that sometimes $\mathrm{X}$ would be applied to people heavily deterred by nonlegal sanctions from engaging in the behavior promoted by $\mathrm{X}$, while sometimes $\mathrm{X}$ would be applied to people who are not influenced by nonlegal sanctions, the analyst would reply that the legal sanctions should be stricter in the first case than in the second. ${ }^{184}$ Only this view explains why most commentators concede the importance of nonlegal sanctions but conduct their legal analyses as though such sanctions did not exist.

In fact, nonlegal sanctions complicate legal analysis considerably. Application of the same law $\mathrm{X}$ to an atomistic collection of people, A, and a solidary group of people, B, can produce dramatically different effects. It might, as the examples of welfare law, antidiscrimination law, and employment law show, make the people in A wealthier while making the people in B poorer. It might, as the discussion of dispute resolution shows, reduce the number of disputes that arise in A while increasing the number of disputes arising in $\mathrm{B}$. In short, it might encourage people in A to engage in the desired behavior while discouraging people in $\mathrm{B}$. Legal analysts and judges must pay closer attention to the sociological contexts to which their analyses apply. ${ }^{185}$

in a Nutshell at 3-6 (cited in note 80); the law of nonprofit organizations, see Henry B. Hansmann, The Role of Nonprofit Enterprise, 89 Yale L J 835, 894 (1980); the law of worker ownership, see Henry Hansmann, When Does Worker Ownership Work? ESOPs, Law Firms, Codetermination, and Economic Democracy, 99 Yale L J 1749, 1809-10 (1990); and the law governing political parties and organizations-for which, however, a sizable literature already exists, see, for example, Wilson, Political Organizations at 337-40 (cited in note 69).

18s Conversely, if the nonlegal sanctions independently promote behavior consistent with $\mathrm{X}$, then the analyst would advocate weaker sanctions for the people influenced by the nonlegal sanctions.

${ }_{185}$ An interesting illustration of such attention is State $v$ Lentz, 70 Ohio St 3d 527, 639 NE2d 784 (1994). In that case, the court said that, although one cannot expect a private lawyer to assert the incompetence of an officemate in order to obtain a reversal of a conviction, a public defender can be expected to assert the incompetence of another public defender in the same office. Therefore, a criminal defendant may be barred by res judicata from asserting a new claim of ineffective assistance of counsel in the second case, but not in the first. Id at 785. The majority based this distinction on the profit motive of the private firm. Id at 786. The dissent, on the other hand, pointed out that the nonlegal sanctions in a public defender's office provide as strong an incentive not to expose a colleague's incompetence as does the profit motive in the firm. Id at 787 (Wright dissent- 
This discussion resonates with other debates in social and legal theory. For instance, others have argued that self-regulating groups must be contrasted with the market and the state to determine the optimal means of social organization. They have pointed out that when the market supplies goods efficiently or the state supplies goods efficiently, solidary groups are injured because members can obtain the goods supplied by the groups from the market or the state. ${ }^{186}$ Writers have addressed the potential efficiency losses resulting from substitution of market and state mechanisms for group mechanisms. ${ }^{187}$ They have not, however, adequately addressed the ways in which the state can use legal means to protect and exploit the efficiency-enhancing aspects of solidary groups. Nor have they addressed the ways in which existing law responds to or neglects these phenomena.

The conventional, superficial understanding of the interaction between legal and nonlegal sanctions has marred several lines of analysis. First, a naive view of the state's ability to promote groups underlies the various proposals for using groups to solve social problems. I have discussed Rose's women's groups. ${ }^{188}$ Others have pushed groups to the forefront of discussions on race relations, ${ }^{189}$ and, of course, the group is an important theme in discussions of labor and interpersonal relations. ${ }^{190}$ None of these discussions, however, takes sufficient account of the complexities of group behavior.

Second, arguments about market failures and other sorts of problems routinely assume that the state should intervene in a direct way, that is, with category-based rules and intrusive dispute resolution rules. An example is Cass Sunstein's argument that addiction, myopia, sour grapes, lack of information, and

ing).

Iss See, for example, Hechter, Principles of Group Solidarity at 48 (cited in note 12); Michael Taylor, Anarchy and Cooperation 132-40 (Wiley 1976).

is $\mathrm{R}$ Recent contributions to the literature on the private provision of public goods have discussed this problem. See, for example, Bergstrom, Blume, and Varian, 29 J Pub Econ at 46-47 (cited in note 43). See also Robert P. Inman, Markets, Governments, and the "New" Political Economy, in Alan J. Auerbach and Martin Feldstein, eds, 2 Handbook of Public Economics 647, 692 (North Holland 1987).

${ }_{189}$ See Rose, $78 \mathrm{Va} \mathrm{L} \mathrm{Rev} \mathrm{at} \mathrm{455-58} \mathrm{(cited} \mathrm{in} \mathrm{note} \mathrm{170).} \mathrm{See} \mathrm{also} \mathrm{text} \mathrm{accompanying}$ notes 170-73.

${ }_{159}$ See, for example, Anthony D. Taibi, Banking, Finance, and Community Economic Empowerment: Structural Economic Theory, Procedural Civil Rights, and Substantive Racial Justice, 107 Harv L Rev 1463, 1544 (1994).

${ }_{159}$ Summers, $141 \mathrm{U} \mathrm{Pa} \mathrm{L}$ Rev at 537-38 (cited in note 135) (labor relations); Robert N. Bellah, et al, Habits of the Heart: Individualism and Commitment in American Life 141 (Berkeley 1985) (interpersonal relations). 
other problems relating to the formation of preferences justify state intervention. ${ }^{191}$ This discussion typifies legal scholarship in that it compares state intervention and the market, without considering the possibility of delegating power to groups. But for the subtle and information-sensitive task of transforming the preferences of people suffering from addiction, myopia, sour grapes, and lack of information, subsidization of certain groups that attack these problems-especially, families and religious groups-is a plausible and perhaps superior alternative to state regulation.

Third, philosophical debates about the role of the state and the roles of groups in political life often neglect the legal implications of state control of groups. In recent arguments between liberals and communitarians, for example, the concept of the group has played a surprisingly minor role. ${ }^{192}$ On the one hand, for the communitarians, a great deal turns on the extent to which groups solve the problems supposedly produced by the liberal state. ${ }^{193}$ On the other hand, neither liberals nor communitarians say much about how groups work and how the state can or cannot encourage or suppress groups. ${ }^{194}$ The argument proceeds at a high level of abstraction. But political ideals must eventually be grounded in legal possibility. What is needed,

${ }^{191}$ See Cass R. Sunstein, Legal Interference with Private Preferences, 53 U Chi L Rev 1129, 1158-73 (1986).

192 See, for example, Symposium, The Republican Civic Tradition, 97 Yale L J 1493 (1988). Several contributors address autonomous groups, pointing out their benefits (political participation) and their dangers (coercion, faction). See, for example, Frank Michelman, Law's Republic, 97 Yale L J 1493, 1531-32 (1988); Cass R. Sunstein, Beyond the Republican Revival, 97 Yale L J 1539, 1572-76 (1988); Kathleen M. Sullivan, Rainbow Republicanism, 97 Yale L J 1713, 1722-23 (1988) (pointing out ambiguities in Michelman's and Sunstein's positions with respect to groups). For a general critique from a political party perspective, see Michael A. Fitts, The Vices of Virtue: A Political Party Perspective on Civic Virtue Reforms of the Legislative Process, 136 U Pa L Rev 1567 (1988).

${ }^{193}$ However, communitarians are obscure about how and whether the state should support groups. Nothing in communitarianism suggests that all groups are good, or that the state should indiscriminately support all groups. For a discussion of these problems, see Hardin, One for All at 183-86 (cited in note 12). Still, political and social theorists have made powerful arguments that the effectiveness of political and economic institutions depends heavily on civil society. See especially Robert D. Putnam, Making Democracy Work: Civic Traditions in Modern Italy 171-76 (Princeton 1993). This suggests that the use of laws in a manner that is sensitive to the solidarity of groups has a powerful pragmatic justification.

${ }_{194}$ On liberals' neglect of groups, see, for example, Vernon Van Dyke, The Individual, the State, and Ethnic Communities in Political Theory, 29 World Pol 343, 346-49 (1977) (discussing Hobbes, Locke, and Rousseau). See Jean-Jacques Rousseau, The Social Contract 73 (Penguin 1968) (Maurice Cranston, trans) ("II]f the general will is to be clearly expressed, it is imperative that there should be no sectional associations in the state ...."). 
but what has been lacking in debates between liberals and communitarians, is a systematic analysis of how the state can use laws to deal with groups, so that the prescriptions of philosophy reflect an adequate understanding of the limitations of the law. 
HeinOnline -- 63 U. Chi. L. Rev. 1981996 